\title{
ipen
}

Autarquia Associada à Universidade de São Paulo

\section{VALORES DE REFERÊNCIA DE ELEMENTOS EM SANGUE DE CAVALOS DA RAÇA CRIOULA VIA METODOLOGIA NUCLEAR}

\section{Tatyana Spinosa Baptista}

Dissertação apresentada como parte dos requisitos para obtenção do Grau de Mestre em Ciências na Área de Tecnologia Nuclear - Aplicações

Orientador:

Dra. Cibele Bugno Zamboni 
INSTITUTO DE PESQUISAS ENERGÉTICAS E NUCLEARES

Autarquia Associada à Universidade de São Paulo

\section{VALORES DE REFERÊNCIA DE ELEMENTOS EM SANGUE DE CAVALOS DA RAÇA CRIOULA VIA METODOLOGIA NUCLEAR}

Tatyana Spinosa Baptista

Dissertação apresentada como parte dos requisitos para obtenção do Grau de Mestre em Ciências na Área de Tecnologia Nuclear - Aplicações

Orientador:

Dra. Cibele Bugno Zamboni 
BOM MESMO É IR À LUTA COM DETERMINAÇÃO, ABRAÇAR A VIDA E VIVER COM PAIXÃO, PERDER COM CLASSE E VIVER COM OUSADIA, POIS O TRIUNFO PERTENCE A QUEM SE ATREVE, E A VIDA É MUITO BELA PARA SER INSIGNIFICANTE.

(Charles Chaplin)

Ao Carlos Maria, minha fonte de inspiração Ao Mário e Valéria, meus maravilhosos pais A Sueli Spinosa, ilustre exemplo de vida 


\section{AGRADECIMENTOS}

A realização deste trabalho não é mérito individual, mas resultado da contribuição de inúmeras pessoas que participaram direta ou indiretamente para o seu desenvolvimento. Agradeço a todas elas e, de forma particular:

A minha orientadora, Dra. Cibele Bugno Zamboni, a dedicação e apoio, e por incentivar, desde o início, em que obteríamos um bom resultado. Este trabalho deve muito às suas sugestões e às nossas reuniões de trabalho;

Ao José Roberto Marcelino, diretor do Serviço de Imunologia do Instituto Butantan, pelo enorme apoio e dedicação na concretização deste trabalho;

A Luciana Kovacs, Sabrina Metairon, Rodrigo Aguiar, Wagner Batista, Ilca Medeiros, José Agostinho Medeiros, Cláudio Domienikan e Fábio Toledo pelo enorme apoio, dedicação e solidariedade entre nós colegas do grupo de pesquisa;

Aos funcionários da Obtenção de Soros Hiperimunes do Instituto Butantan, pela grande ajuda na coleta de material e incentivo na realização deste estudo;

Aos pesquisadores do Ipen, em especial ao Dr. Frederico Genezini e Dr. Guilherme Zahn, por toda sua experiência e competência que me auxiliaram durante estes anos que estive aqui no Ipen;

Aos pesquisadores do Instituto Butantan, por compartilharem seus conhecimentos, enriquecendo a elaboração deste trabalho;

Aos amigos do CRPq que estiveram ao meu redor a compreensão, incentivo, solidariedade e amizade que me deram nos momentos mais difíceis;

Ao IPEN pelo material técnico e pela oportunidade de poder realizar este trabalho. 


\section{VALORES DE REFERÊNCIA DE ELEMENTOS EM SANGUE DE CAVALOS DA RAÇA CRIOULA VIA METODOLOGIA NUCLEAR}

\section{Tatyana Spinosa Baptista}

\section{Resumo}

No presente estudo valores de referência para $\operatorname{Br}\left(0,0008-0,0056 \mathrm{gL}^{-1}\right), \mathrm{Ca}$ $\left(0,089-0,369 \mathrm{gL}^{-1}\right), \mathrm{Cl}\left(2,10-3,26 \mathrm{gL}^{-1}\right), \mathrm{Fe}\left(0,381-0,689 \mathrm{gL}^{-1}\right), \mathrm{I}(0,00018-$ $\left.0,00266 \mathrm{gL}^{-1}\right), \mathrm{K}\left(1,14-2,74 \mathrm{gL}^{-1}\right), \mathrm{Mg}\left(0,030-0,074 \mathrm{gL}^{-1}\right), \mathrm{Na}\left(1,36-2,80 \mathrm{gL}^{-}\right.$ $\left.{ }^{1}\right), \mathrm{P}\left(<1,99 \mathrm{gL}^{-1}\right), \mathrm{S}\left(0,99-2,79 \mathrm{gL}^{-1}\right)$ e $\mathrm{Zn}\left(0,0012-0,0048 \mathrm{gL}^{-1}\right)$ bem como a matriz de correlação em sangue de eqüinos da Raça Crioula foram determinados utilizando metodologia nuclear (técnica de Análise por Ativação com Nêutrons). Estes dados permitiram identificar alterações fisiológicas relacionadas ao gênero e regime de exercício em que se enquadram estes animais (produção de soros hiperimunes no Instituto Butantan, São Paulo, Brasil). Para realização dessas análises foram utilizados 20 cavalos adultos (8 machos e 12 fêmeas) sadios, na faixa etária de 1 a 3 anos e peso médio de $350 \mathrm{~kg}$, mantidos na Fazenda São Joaquim do Instituto Butantan (São Paulo). Outro grupo recém imunizados, composto por 6 cavalos machos (mesmo peso e idade) foram também analisados. Estes dados auxiliaram na interpretação das funções fisiológicas desses elementos no sangue destes animais durante 0 processo de imunização para produção de soros. 


\title{
REFERENCE VALUES IN BLOOD ELEMENTS IN CRIOULA BREED HORSES BY NUCLEAR METHODOLOGY
}

\author{
Tatyana Spinosa Baptista
}

\begin{abstract}
In this study the reference value for $\operatorname{Br}\left(0,0008-0,0056 \mathrm{gL}^{-1}\right), \mathrm{Ca}(0,089-0,369$ $\left.\mathrm{gL}^{-1}\right), \mathrm{Cl}\left(2,10-3,26 \mathrm{gL}^{-1}\right)$, Fe $\left(0,381-0,689 \mathrm{gL}^{-1}\right), \mathrm{I}\left(0,00018-0,00266 \mathrm{gL}^{-1}\right)$, $\mathrm{K}\left(1,14-2,74 \mathrm{gL}^{-1}\right), \mathrm{Mg}\left(0,030-0,074 \mathrm{gL}^{-1}\right), \mathrm{Na}\left(1,36-2,80 \mathrm{gL}^{-1}\right), \mathrm{P}\left(<1,99 \mathrm{gL}^{-}\right.$ $\left.{ }^{1}\right), S\left(0,99-2,79 \mathrm{gL}^{-1}\right)$ and $\mathrm{Zn}\left(0,0012-0,0048 \mathrm{gL}^{-1}\right)$ as well as the correlation matrix in blood of Crioulo breed horses were determined using nuclear methodology (Neutron Activation Analysis Technique). These data allowed to identifying physiological alterations related to the sex and regime of exercise (hyperimmune sera production at Butantan Institute, São Paulo, Brasil). To perform these analyses was used 20 adult horses ( 8 males and 12 females), with average mass $350 \mathrm{~kg}$, without clinical signs of disease, 1-3 years old, kept on pasture in São Joaquim Farm at Butantan Institute (São Paulo city). Other group just immunized, composed by 6 equines males (same age and weight), were also analyzed. These data are an important support to understand the physiological functions of these elements in blood during the process of sera production.
\end{abstract}




\section{SUMÁRIO}

Página

INTRODUÇÃO

OBJETIVO

Capítulo 1 - A importância dos elementos no organismo e nutrição equiina

1.1 Principais características dos elementos e relevância na clínica veterinária............... 7

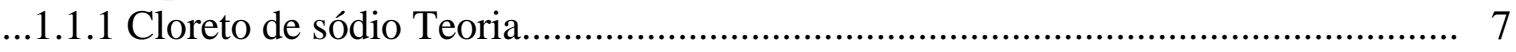

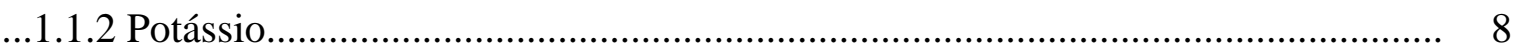

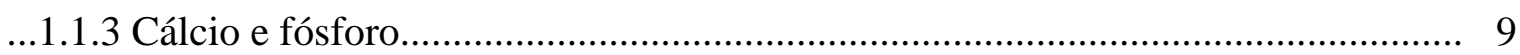

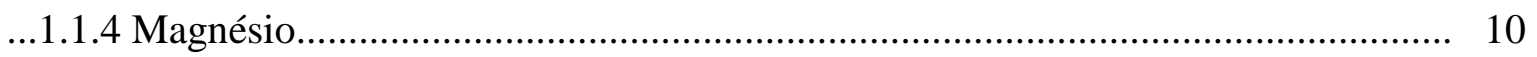

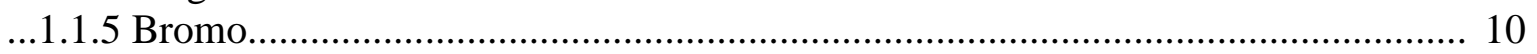

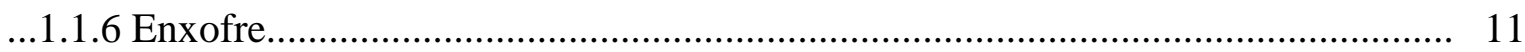

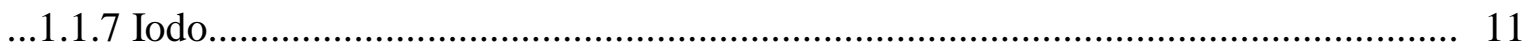

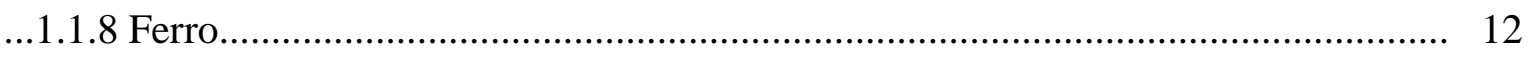

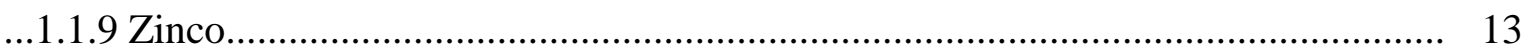

16

Capítulo 2 - O cavalo crioulo

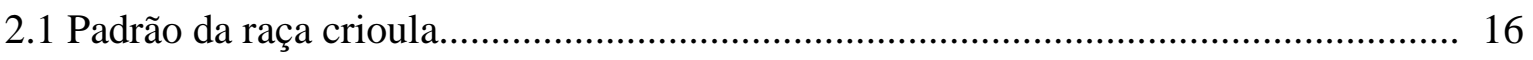

\section{Capítulo 3 - Produção de soros hiperimunes}

3.1 Processo de produção de soros e esquemas de imunização......................................... 21

3.2 Cavalos utilizados na produção de soros hiperimunes do Instituto Butantan............. 22

\section{Capítulo 4 - Metodologia nuclear}

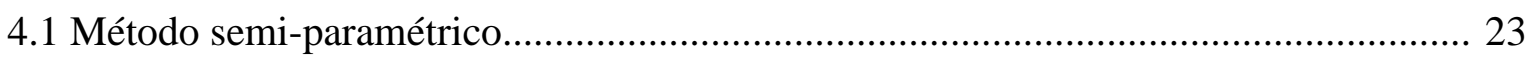

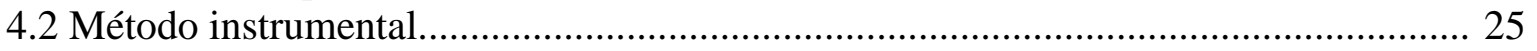

Capítulo 5 - Instrumentação nuclear.

\section{Capítulo 6 - Procedimento experimental}

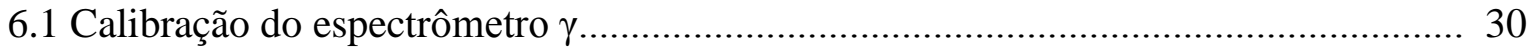

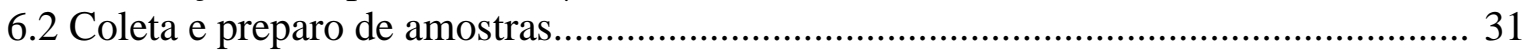




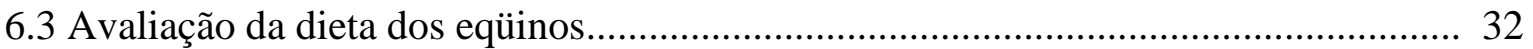

6.4 Avaliação do soro antibotrópico produzido no Instituto Butantan............................ 32

6.5 Irradiação utilizando o método semi-paramétrico de AAN....................................... 33

6.6 Irradiação utilizando o método instrumental de AAN................................................. 33

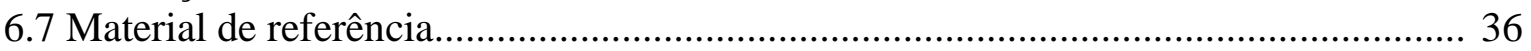

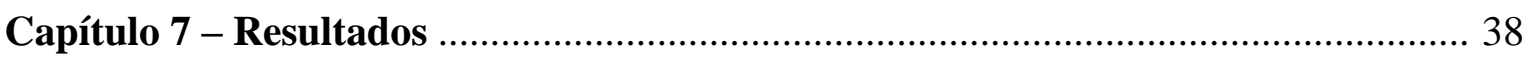

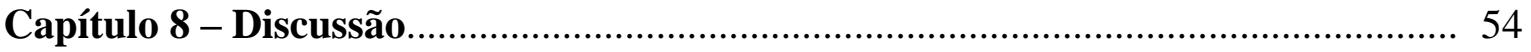

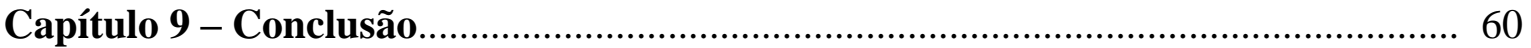

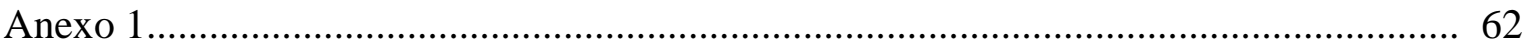

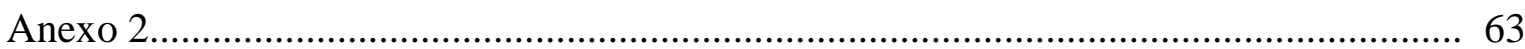

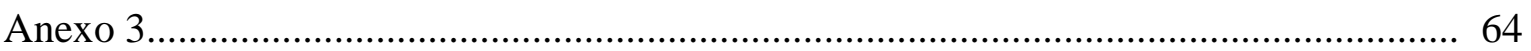

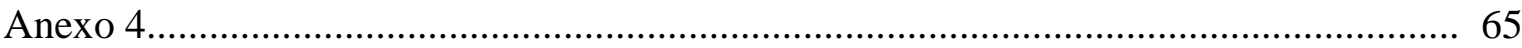

Anexo 5

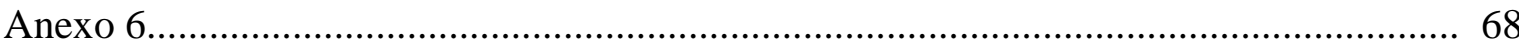

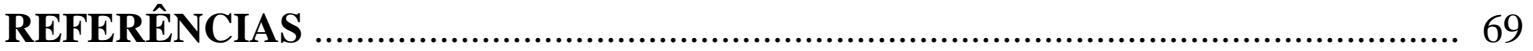




\section{LISTA DE FIGURAS}

Página

Figura 1: Esquema ilustrativo do projeto multidisciplinar........................................ 4

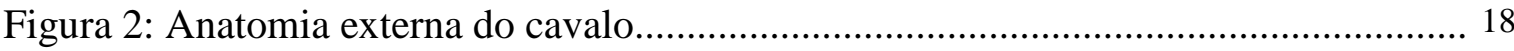

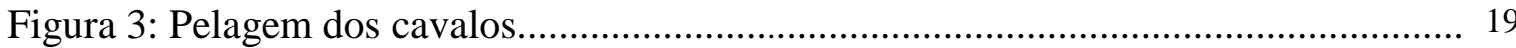

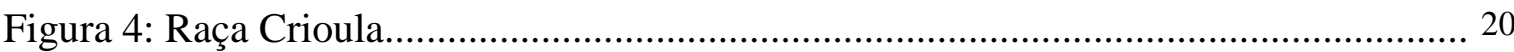

Figura 5: Eqüino da raça Crioula do Instituto Butantan................................................ 20

Figura 6: Instrumentação nuclear utilizada no LEER................................................... 27

Figura 7: Arranjo com detector de germânio hiperpuro (HPGE).................................... 28

Figura 8: Esquema simplificado do arranjo eletrônico utilizado....................................... 29

Figura 9: Função ajuste (em vermelho) e eficiência do fotopico experimental (azul)....... 30

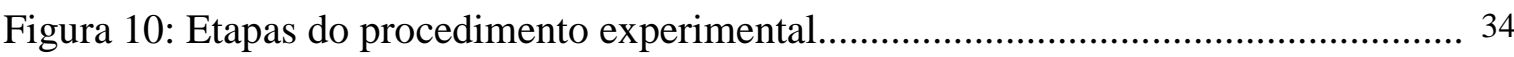

Figura 11: Espectro parcial de raios gama de sangue total de eqüino (GC), utilizando

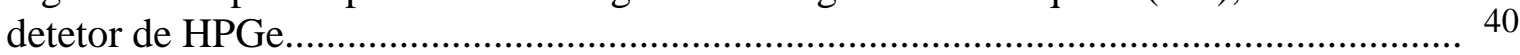

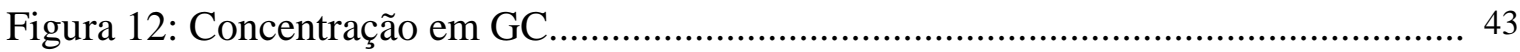

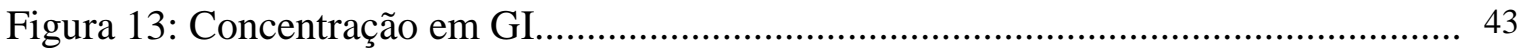

Figura 14: Espectros dos elementos contidos na ração................................................. 51 


\section{LISTA DE TABELAS}

Página

Tabela 1: Descrição do GRUPO CONTROLE (GC).

Tabela 2: Propriedades nucleares relacionadas a seus isótopos: composição isotópica (\%), isótopo a ser ativado; reação induzida por nêutrons $(n, \gamma)$; energia dos raios $\gamma$ emitidos $\left(\mathrm{E}_{\gamma}\right)$ e a meia vida $\left(\mathrm{T}_{1 / 2}\right)$ associada ao isótopo ativado.

Tabela 3: Resultados da AAN comparado com os valores certificados

Tabela 4: Concentração dos elementos investigados no sangue de eqüinos (GC) 41

Tabela 5: Concentração de $\mathrm{Na}, \mathrm{K}, \mathrm{Cl}, \mathrm{Ca}$ investigados no sangue de equinos nos grupos CG (constituídos por machos) e GI.

Tabela 6: Matriz de correlação para os elementos determinados em sangue total para o grupo controle (GC); as relações prioritárias encontram-se em destaque......

Tabela 7: Concentração dos minerais na ração

Tabela 8: Concentração dos minerais no sal.

Tabela 9: Concentração dos minerais no soro antibotrópico (antiveneno)

Tabela 10: Matriz de correlação em sangue total para os elementos determinados em sangue total no grupo controle (machos); as relações prioritárias encontram-se em destaque

Tabela 11: Matriz de correlação em sangue total para os elementos determinados em sangue total no grupo imunizado (GI); as relações prioritárias encontram-se em destaque 


\section{INTRODUÇÃO}

A criação de cavalos da raça Crioula está se desenvolvendo cada vez mais no país. Trata-se de uma raça nacional rústica, empregada tanto no trabalho rural como em competições [1]. No Instituto Butantan, estes animais em especial já vêm sendo utilizados na produção de soros hiperimunes desde meados do século passado. Apesar disso, são escassas as informações a respeito de padrões hematológicos de referência para esta raça [2].

Os minerais (eletrólitos presentes no sangue) são elementos inorgânicos que têm papel importante na química do organismo, sendo essenciais em diversas funções: formação do esqueleto, dentes e células sanguíneas; equilíbrio dos fluídos nos compartimentos orgânicos; regulação da atividade da tireóide; metabolismo celular, etc. Os efeitos das deficiências dos minerais são normalmente subclínicos e não são reconhecidos ou atribuídos a deficiências específicas [3]. Em contrapartida, o excesso destes elementos pode acarretar interferências na absorção de outros minerais.

Atualmente no guia de referência veterinário MERCK, podemos encontrar valores de alguns eletrólitos em soro de eqüinos [4], sem especificação da raça ou ramo de atividade que estes eqüinos desempenham.

Desta forma, justifica-se a busca de métodos que forneçam uma análise quantitativa dos elementos constituintes dos fluídos corpóreos nesses animais de forma ágil, precisa e principalmente minimizando o estresse dos mesmos, com o objetivo de obter valores de referência que podem ser utilizados como mais uma ferramenta na avaliação clínica destes cavalos que desempenham esta peculiar atividade (produção de soros hiperimunes).

Em vista disto, nos últimos anos o Laboratório de Espectroscopia e Espectrometria das Radiações (LEER) do Centro do Reator de Pesquisas (IPEN/CNEN-SP) tem utilizado a técnica de Análise por Ativação com Nêutrons (AAN) como alternativa para análise de órgãos, ossos e fluídos corpóreos de 
animais de pequeno e médio porte [5-14], simplificando etapas tanto no manuseio como no preparo das amostras, além de fornecer uma análise quantitativa precisa de vários elementos de interesse em bioquímica clínica simultaneamente. Recentemente, a análise de $\mathrm{Ca}, \mathrm{Cl}, \mathrm{Fe}, \mathrm{K}, \mathrm{Mg}$ e $\mathrm{Na}$ em soro humano permitiu validar esta metodologia nuclear para uso em análises hematológicas, pois os resultados obtidos via AAN [15-18], encontram-se em acordo com o estabelecido pela clínica convencional [19].

\section{MOTIVAÇÃO}

A utilização da técnica AAN apresenta um diferencial importante no que se refere às análises bioquímicas convencionais, a saber: utilização de sangue total, dispensando o uso de anticoagulantes e excluindo a necessidade da separação soro - sangue; redução significativa da quantidade de material biológico necessário para execução (de 100 a $500 \mu \mathrm{L}$ ); obtenção simultânea de elementos diversos em sangue total, o que nem sempre é possível via procedimento convencional [19].

Essas simplificações levam também à redução nos custos dos experimentos, pois dispensa o uso de reagentes, além de apresentar facilidades no armazenamento e transporte da amostras, pois não necessita de refrigeração podendo ser armazenada por longos períodos. Além disso, por se tratar de um método não destrutivo, permite repetir a análise sempre que necessário após o término de sua atividade residual (dias).

Particularmente neste estudo, foi realizado a monitoração via AAN em sangue de animais não imunizados (grupo controle) e animais submetidos a uma única imunização (com uma mistura de veneno de cinco espécies do gênero Botrópico), com o intuito de obter dados que permitam identificar alterações fisiológicas relacionadas à sexo, manejo, estado nutricional e regime de exercício em que se enquadram estes animais. 
Este estudo faz parte de um projeto multidisciplinar denominado "Estudo da Distribuição de Metais em Amostras Biológica via Metodologia Nuclear: Determinação de Valores de Referência em humanos e modelo animal", atualmente em desenvolvimento no Laboratório de Espectroscopia e Espectrometria das Radiações (LEER) IPEN/CNEN - SP, em colaboração com Universidades e Centros de Pesquisa de várias regiões do Brasil.

$\mathrm{Na}$ Figura 1 é apresentado um esquema ilustrativo do projeto multidisciplinar no qual o presente estudo está inserido. 


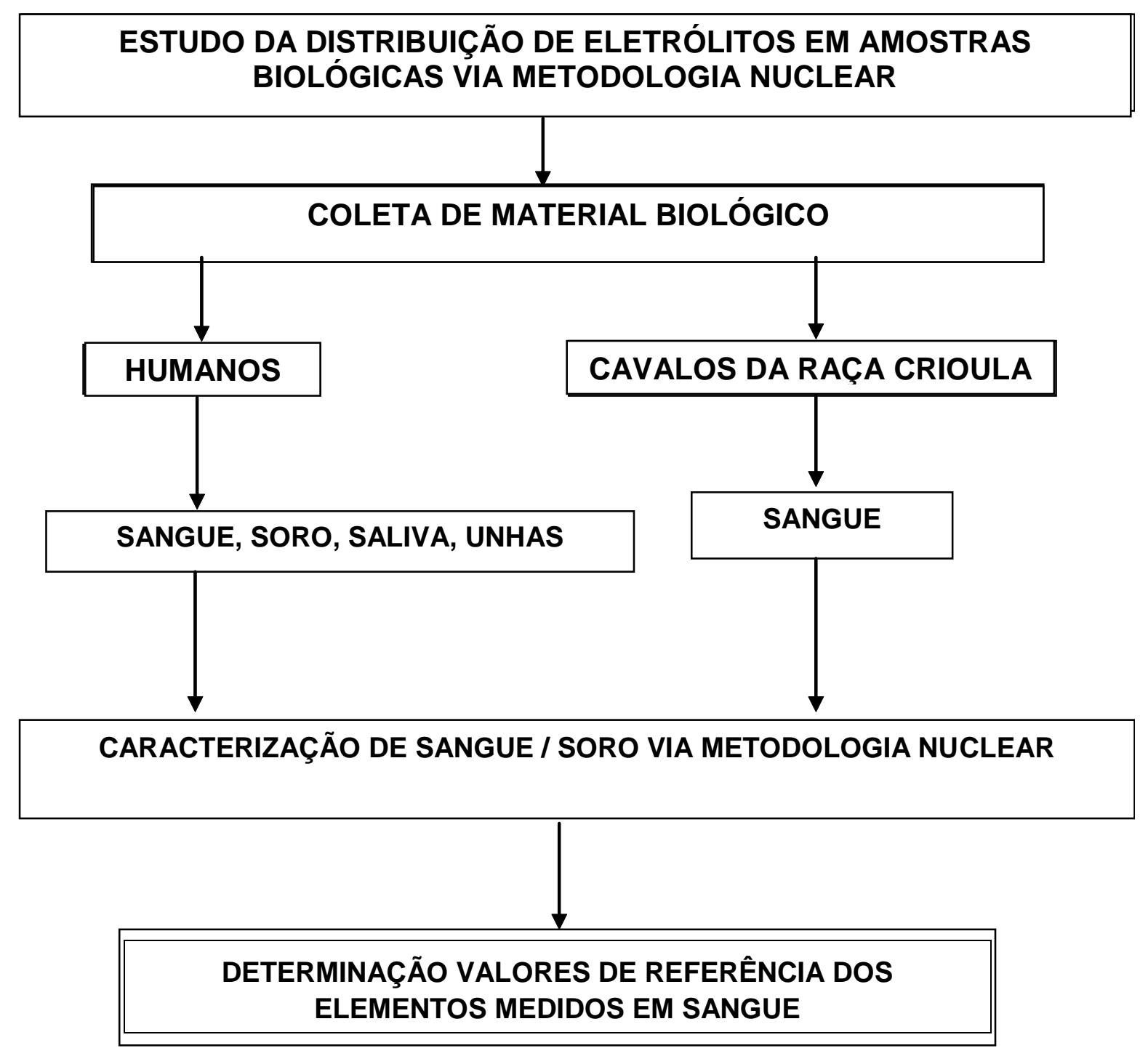

Figura 1 - Esquema ilustrativo. 


\section{OBJETIVO}

Estabelecer valor de referência (índice de normalidade) dos elementos de relevância em bioquímica clínica $(\mathrm{Br}, \mathrm{Ca}, \mathrm{Cl}, \mathrm{K}, \mathrm{Mg}, \mathrm{Na}, \mathrm{Fe}, \mathrm{I}, \mathrm{P}, \mathrm{S}$ e Zn) em sangue de cavalos da raça Crioula, utilizando a técnica de Análise por Ativação com Nêutrons (AAN). 


\section{CAPÍTULO 1. A IMPORTÂNCIA DOS ELEMENTOS NO ORGANISMO E NUTRIÇÃO EQUINA}

Embora sejam importantes para várias funções, os elementos inorgânicos ou minerais constituem somente uma pequena fração do peso corporal e da quantidade de nutrientes exigidos na ração. Em uma base de peso, o corpo do eqüino consiste de aproximadamente 60 a $65 \%$ de água; 30 a $35 \%$ dos nutrientes de fonte energética (proteínas, gorduras e carboidratos) e $4 \%$ de minerais [21].

Os minerais são divididos em macrominerais e minerais vestigiais (microminerais). Os macrominerais (cálcio, fósforo, sódio, cloro, potássio, magnésio e enxofre) são necessários para estrutura corporal, manutenção dos equilíbrios ácido-básico e hídrico corporais, potenciais transmembrânicos para as funções celulares, condução nervosa e contração muscular.

Os minerais vestigiais (cobre, iodo, manganês, zinco, flúor, ferro, selênio, cobalto) são componentes de metaloenzimas, que controlam diversas reações biológicas [21].

Em geral os minerais (macrominerais e vestigiais) podem ser encontrados em excesso e/ou deficiência e/ou equilíbrio no organismo destes animais por diversas razões: ração com índices de exigência de minerais inadequados; tipo de atividade em que o cavalo é submetido; idade; raça; temperamento; digestibilidade individual; clima; baia ou pastagem. Geralmente os efeitos das deficiências dos minerais são normalmente subclínicos nos eqüinos e não são reconhecidos ou atribuídos a deficiências específicas dos minerais [3].

Como no caso de todos os nutrientes da dieta eqüina, para se preencher as exigências de um animal não só a ração deve conter as quantidades adequadas dos nutrientes como também o animal deve-se encontrar capaz de absorvê-los e utilizá-los. Outro fator a se considerar é que a presença de certos minerais na ração pode diminuir a absorção de outros, levando em consideração 
a relação concentração excessiva deste mineral. Atualmente existem muitas lacunas na legislação que regula o setor de alimentos para os animais, sendo que a qualidade da matéria-prima, a forma de armazenamento e o transporte podem influenciar na eficácia da dieta dos eqüinos.

\subsection{Principais características dos elementos \& relevância na clínica veterinária}

\subsubsection{Cloreto de sódio}

O sal para o equilíbrio possuir um papel importante na estabilização do sistema nervoso, músculos e sistema digestório.

O sódio é o único mineral para o qual existe um apetite claramente definido e, portanto se disponível, será consumido por animais em uma quantidade suficiente para preencher suas exigências. Podem-se preencher as exigências de sal dos eqüinos através do fornecimento do sal em bloco ou a granel, embora o consumo da forma a granel seja geralmente maior.

O consumo excessivo de sódio aumenta o volume sanguíneo e a liberação do fator natriurético atrial (que aumenta a diurese do sódio). Como resultado, os eqüinos toleram níveis altos de consumo de sal, contanto que eles tenham acesso suficientemente de água não salina. A toxicose por sal ocorre como resultado de três aspectos: eqüinos bebendo água salgada (provavelmente uma concentração de sódio de $1 \%$ ou mais), devido a não disponibilidade de outro tipo de água; fornecimento de sal a eqüinos com fome de sal; inclusão de $2 \%$ ou mais de sal na ração sem ter água adequada disponível. Os sinais clínicos da toxicose por sal incluem cólicas, diarréia, micção freqüente, fraqueza, cambaleios, paralisia dos membros posteriores, decúbito e morte.

Deficiências de sal podem causar fadiga, desidratação, diminuição na capacidade de trabalho, incapacidade de transpirar e perda de peso. Caso ela 
ocorra nos eqüinos muito rapidamente, a contração muscular e a mastigação tornam-se descoordenadas, a andadura torna-se instável e as concentrações plasmáticas de sódio e cloreto diminuem, enquanto o potássio aumenta. Esta insuficiência do sal pode levar o cavalo a adquirir hábitos indesejáveis como, por exemplo, o de comer as fezes numa tentativa de repor o nível de cloreto de sódio. [21]

\subsubsection{Potássio}

Potássio é um elemento intracelular envolvido no equilíbrio ácidobásico, na manutenção da pressão osmótica e transmissão nervosa.

O consumo excessivo de potássio não é perigoso, a menos que se diminua a excreção renal, pois os excessos são facilmente excretados na urina. Mas, no caso dos eqüinos tem-se uma exceção, pois causa paralisia periódica induzida por potássio, que é uma doença genética incomum.

A fadiga, fraqueza muscular, letargia, intolerância a exercícios e redução do consumo hídrico e alimentar constituem os principias efeitos de deficiência de potássio.

O tratamento da deficiência de potássio inclui um aumento de potássio na dieta ou uso de fluídos de eletrólitos via oral. [21]

\subsubsection{Cálcio e fósforo}

O cálcio e o fósforo compreendem cerca de $70 \%$ do conteúdo mineral do corpo. Cerca de $99 \%$ do cálcio e mais de $80 \%$ do fósforo do corpo encontramse nos ossos e dentes.

O fósforo é importante no metabolismo celular, em especial pela sua participação direta nos mecanismos bioquímicos ligados ao metabolismo 
energético. Sendo assim, o fósforo tem ampla participação no metabolismo de carboidratos, lipídios, proteínas e ácidos nucléicos [22].

O cálcio é necessário para diversas funções: coagulação sanguínea, atuando como cofator metálico na passagem da protrombina à trombina e também de outras enzimas; liberação de insulina das células $\beta$ das ilhotas de Langherans do pâncreas, influenciando desse modo o metabolismo dos carboidratos; contração muscular; atua na permeabilidade da membrana celular e dos capilares; atua na secreção glandular; participa da regulação da temperatura; ativa a transmissão do impulso nervoso na excitabilidade neuromuscular e antagoniza a ação do sódio e do potássio sobre o coração [22].

O cálcio total do sangue está distribuído em pelo menos duas frações bem características: a fração não difusível de Ca-proteína, isto é, cálcio ligado a proteína e uma fração de cálcio ionizado difusível e que apresenta importância fisiológica [22]. Caso se aumente ou reduza significativamente a concentração plasmática de cálcio ionizado, ele apresenta o efeito oposto na excitabilidade da membrana muscular, ou seja, a hipercalcemia diminui e a hipocalcemia aumenta o tônus muscular. Esses efeitos só ocorrem caso se altere a concentração de cálcio livre ou ionizado, já que esta é a única forma biologicamente ativa do cálcio [21]. O cálcio livre (cálcio ligado a proteína principalmente a albumina, compreende cerca de metade do cálcio sanguíneo [22].

As deficiências ou excessos dietéticos de cálcio e fósforo resultam na mobilização ou deposição excessivas desses minerais nos ossos, provocando osteopatia. No entanto, esses efeitos mantêm as concentrações plasmáticas e, portanto, as funções não esqueléticas. Consequentemente, as doenças esqueléticas e renais constituem o principal efeito de uma deficiência ou excesso dietético tanto de cálcio como de fósforo.

Os eqüinos são mais prováveis de sofrer uma falta de cálcio ou de fósforo (levando a doenças esqueléticas) do que da falta de qualquer outro mineral. 
O único papel clinicamente importante do excesso do fósforo dietético para o eqüino é que o excesso de fósforo se conjuga com o cálcio, diminuindo sua absorção. Esse efeito se torna mais prejudicial quanto menor for o teor de cálcio na ração e a idade do animal [21].

\subsubsection{Magnésio}

O magnésio, um íon intracelular, exerce amplo papel no organismo por ser ativador de muitas enzimas envolvidas em processos ligados ao metabolismo energético, ao metabolismo dos ácidos nucléicos e a biossíntese de proteínas [22].

Os sintomas gerais de deficiência de magnésio relatada em eqüinos são: convulsões que se iniciam na presença de ruídos, já que a irritabilidade tecidual é sensível às concentrações do magnésio sérico, nervosismo, tremores musculares, ataxia, e tetania antes da morte. Além disso, os eqüinos demonstram lesões da musculatura cardíaca e esquelética e deposição de cálcio na porção ascendente da alça de Henle. [22].

Por outro lado, não se sabe se o consumo excessivo de magnésio por parte de um eqüino é perigoso. Não se observou nenhum efeito colateral nos eqüinos alimentados com rações que continham 0,86\% de magnésio por um mês, com a fonte principal de magnésio sendo o óxido de magnésio. Embora o consumo excessivo de magnésio por parte do eqüino aumente a absorção de cálcio, o excesso de ambos é excretado na urina [21].

\subsubsection{Bromo}

O Bromo é considerado um elemento químico essencial, entretanto ainda não se conhece exatamente as funções que realiza. Muitos compostos de bromo têm uma ação fisiológica importante, por isso são utilizados como sedativos, anestésicos e anti-sépticos. $\mathrm{O} B r$ embora não seja majoritário no 
sangue, sua monitoração clínica esta normalmente relacionada a intoxicação por medicamentos.

\subsubsection{Enxofre}

O enxofre é constituinte de vários aminoácidos, vitaminas, coenzimas, etc. A concentração dos aminoácidos que contêm enxofre é mais alta nos cascos e nos pêlos, que contêm a proteína queratina (que possui $4 \%$ de enxofre). Ainda não se determinaram as exigências de enxofre para os equinos em relação a sua deficiência ou excesso [21].

\subsection{7 lodo}

A única função conhecida do iodo e a razão para a sua necessidade na ração é a síntese dos hormônios tireoideanos que contêm iodo. Independente da exigência ou da quantidade ingerida, quase todo o iodo dietético é convertido em iodeto e absorvido pelo trato gastrointestinal.

Uma deficiência ou uma toxicose (excesso) por iodo pode resultar em hipotireoidismo e hipertrofia da glândula tireóide ou bócio. No caso de deficiência de iodo, encontra-se disponível uma quantidade insuficiente de iodeto para sintetizar uma quantidade adequada de hormônios tiroideanos que contêm iodo. No caso de toxicose por iodo, por outro lado, o excesso de iodeto inibe a síntese e/ ou a liberação de hormônios tireoideanos através de seu efeito direto na glândula tireóide.

Os efeitos de uma deficiência ou toxicose por iodo incluem: um pelame opaco e seco e queda de pêlos; ocasionalmente um espessamento cutâneo devido ao acúmulo de material mucinoso sob a pele, chamado de mixedema, particularmente nos membros distais dos potros deficientes de iodo; no feto ou nos animais jovens, uma diminuição do crescimento e da calcificação óssea, que nos casos severos pode resultar em deformidades esqueléticas que levam a 
extremidades fortes e grosseiras e um corpo pequeno, em um fenômeno chamado de cretinismo.

Geralmente faz-se o diagnóstico da deficiência e do excesso de iodo através das concentrações plasmáticas de $\mathrm{T}_{4}$ e $\mathrm{T}_{3}$. Nos eqüinos adultos, os níveis dos hormônios tireoideanos diminuem com a idade e com o excesso de proteínas dietéticas. As concentrações de $T_{4}$ também são baixas em eqüinos que ingeriam rações contendo excesso de zinco e cobre e tendem a serem mais elevadas em eqüinos que ingeriam rações ricas em manganês e magnésio. Contrariamente, as concentrações séricas de $T_{3}$ não são afetadas de nenhuma maneira específica pela ração.

O tratamento da deficiência ou da toxicose por iodo consiste na correção do desequilíbrio dietético presente. No entanto, como ambas as afecções podem causar hipotireoidismo e sintomas semelhantes, é importante determinar se os eqüinos consumiram pouco ou muito iodo, através da avaliação da ração e do sal [21].

\subsubsection{Ferro}

O ferro é essencial como constituinte de moléculas e enzimas envolvidas no transporte e no uso do oxigênio. Ele se distribui primariamente na hemoglobina sanguínea (60\% do ferro do corpo), na mioglobina muscular (20\%), nas formas de armazenamento (conjugadas com a ferritina e a hemossiderina) e nas formas de transporte (conjugadas com a transferrina). A absorção do ferro diminui com o consumo excessivo de cádmio, cobalto, cobre, manganês e zinco.

Especula-se que as exigências de ferro sofrem um acréscimo com 0 aumento do exercício físico, devido à perda de ferro no suor e ao aumento da destruição eritrocítica. No entanto, o aumento da destruição eritrocítica não aumenta as exigências dietéticas de ferro, pois o ferro proveniente dessas células é reutilizado para a síntese de novas hemácias. Além disso, o exercício físico aumenta as exigências energéticas dietéticas. Portanto, consome-se mais alimento e, assim, mais ferro. Como resultado, se as exigências de ferro 
aumentam com o aumento do exercício físico, o aumento não é suficiente para causar uma deficiência de ferro, e não há nenhum benefício na administração ou na suplementação de ferro.

Uma deficiência de ferro só ocorre nos eqüinos se houver perda sanguínea crônica ou severa, raramente devido a uma deficiência na ração. $A$ perda sanguínea pode ser inaparente, tal como devida a infestação com piolhos ou a parasitismo intestinal severo. O efeito inicial de uma deficiência de ferro é uma diminuição no armazenamento de ferro no fígado, baço e medula óssea, simultânea a uma diminuição na concentração plasmática de ferritina. A diminuição no ferro iônico exigido como cofator nas enzimas envolvidas em determinadas reações-chave diminui a capacidade de exercício. Isso ocorre antes de uma anemia e o animal anêmico deficiente em ferro responde a uma administração de ferro com um aumento na capacidade de resistência antes de ocorrer um aumento significativo na concentração hemoglobínica.

O excesso de ferro é raramente dietético em eqüinos e só ocorre quando há excesso de administração deste elemento na dieta, especialmente se houver deficiência de vitamina $E$ em potros. Neste caso o consumo excessivo de ferro dietético pode diminuir a absorção de outros minerais o que, se for suficiente, resulta em deficiências desses minerais.[21]

\subsubsection{Zinco}

O zinco é essencial para o desenvolvimento, crescimento, função imune e diferenciação de tecidos de todas as espécies.

A deficiência de zinco causa rápida atrofia do timo e alterações funcionais das células $T$ e células natural killer (NK), o que resulta em diminuição da produção e atividade dos hormônios tímicos, de certas classes de anticorpos, da citotoxicidade mediada por células, da função neutrofílica e produção de linfocinas. 
O estresse da prenhez e lactação aumentam as necessidades de zinco, conforme o grau de perdas como suor profuso e infecções parasitárias com perda de sangue. A deficiência de zinco pode diminuir a secreção de testosterona, insulina e corticóides da adrenal, afetando, assim, a espermatogênese e o desenvolvimento de órgãos sexuais primários e secundários de machos e todas as fases reprodutivas das fêmeas.

O retardo do crescimento é universalmente observado na deficiência do zinco, devido à diminuição da síntese de ácido nucléico, à diminuição da utilização dos aminoácidos e da síntese protéica em geral. Ocorre ainda, alteração óssea, com prejuízo da síntese do colágeno e redução da atividade da colagenase tibial [23].

O eqüino é bastante resistente a um consumo alto de zinco. Embora o excesso de zinco diminua a absorção de cobre nos ruminantes, um teor de zinco de 580 e 1.200 mg/kg de matéria seca da ração não diminui a absorção de cobre em um eqüino. No entanto, mais de $700 \mathrm{mg} / \mathrm{kg}$ parecem interferir na utilização do cobre por outros meios além da diminuição da sua absorção, resultando em DOD. A DOD constitui uma manifestação consistente do excesso do consumo de zinco nos eqüinos, suínos, bovinos e ratos jovens. Já se descreveram derrames tibiotarsais, epifisite e inchaço articular crônico, seguidos por um descolamento cartilaginoso articular a partir do osso subjacente, lesões radiográficas semelhantes às da osteocondrite dissecante e deformidades de flexão nos eqüinos jovens como resultado de excesso de zinco dietético. Inicialmente ocorrem aumentos de volume das regiões epifisárias dos ossos longos sem dor aparente. Isso é seguido por claudicação com uma andadura rígida ou relutância em se mover. Os potros severamente afetados frequentemente ficam em pé com sua cabeça abaixada, apresentam arqueamento do dorso e resistem a curvar a espinha lateralmente quando virados parar o lado. Também podem ocorrer diminuição da taxa de crescimento, mau condicionamento e anemia progressiva. Os potros alimentados com $90 \mathrm{mg}$ de zinco/kg de peso corporal (equivalentes a $3,6 \mathrm{~g} / \mathrm{kg}$ de matéria seca da ração) desenvolveram anemia e apresentaram diminuição do crescimento, aumento de volume das placas de crescimento dos 
ossos longos das pernas, rigidez, claudicação e aumento das concentrações sanguinea e tecidual de zinco.

A maioria dos casos clínicos de toxicose por zinco se deve a pastos contaminados por meio de poluição aerógena proveniente de fundições ou minas de zinco, fundições de bronze e outras indústrias, tais como as fábricas de ferro galvanizado. As outras causas incluem recobrimento dos pastos com óxido de zinco, excesso de zinco nas misturas de grãos devido a erros de mistura e excesso de zinco na água. O zinco pode ser liberado na água através de eletrólise quando se juntam canos galvanizados e de cobre [21]. 


\section{CAPÍTULO 2. O CAVALO CRIOULO}

O cavalo crioulo constitui-se em uma raça ideal para o serviço de campo por apresentar evidente rusticidade, qualidade esta relacionada a baixa necessidade nutricional. Segundo Afonso \& Correa [1], o Crioulo tem o quarto maior plantel registrado no Brasil, sendo que dos 92 mil animais existentes no país, 60 mil são relativos ao Rio Grande do Sul, ocupando, em conseqüência, uma expressiva posição econômica.

A raça Crioula foi a primeira raça sul-americana formada nos campos úmidos da Bacia da Prata, descendendo em linha direta dos cavalos ibéricos trazidos pelos espanhóis e portugueses ao longo do século XVI para as regiões que formariam a Argentina, o Paraguai e o Brasil. Sendo oriundos do cruzamento de cavalos árabes e berberes (cavalos oriundos do Norte de África), constituemse de animais dóceis e de fácil aprendizado, sendo utilizados também para rodeios [24]. Segundo Beck [25], é um cavalo que apresenta qualidades como grande fertilidade, facilidade de adaptação, habilidade para apartação e lida com o gado.

Em se tratando de uma raça que apresenta características que atraem o interesse dos mais variados criadores, para os mais variados serviços, é necessário um trabalho árduo de médicos veterinários e pesquisadores sobre esta raça, requerendo manejo, avaliação e prevenção de doenças adequados para que se alcance o máximo desempenho do animal.

\section{1 - Padrão da Raça Crioula}

- Cabeça: curta, em fora de pirâmide, ampla na base, afinando para o focinho;

- Maxilares fortes e bem desenvolvidos; crânio amplo. Olhos grandes, afastados e expressivos.

- Pescoço: bem unido à cabeça por uma garganta limpa e larga; quase reto em sua linha inferior, amplo, largo e forte, musculoso na sua inserção com o tórax. 
- Cernelha (é a parte do corpo do cavalo que faz união do seu pescoço com o dorso. Em seu ponto mais alto é onde se mede a altura absoluta do cavalo.): musculosa, pouco saliente, larga e forte.

- Dorso: reto, curto, largo, bem unido à cernelha, denotando capacidade de suportar e carregar peso.

- Lombo: curto, largo, musculoso, forte, bem unido ao dorso, com o qual deve manter perfeita harmonia de conjunto.

- Garupa: de largura média, musculosa, forte, bem desenvolvida, semi-oblíqua.

- Cauda: com sabugo grosso e curto, bem implantada, com abundância de crinas.

- Peito: amplo, largo e profundo, fortemente musculado, possuindo um grande perímetro, qualidade muito apreciada.

- Ventre: cilíndrico, volumoso quando a sua alimentação é grosseira, reduzindo o volume quando ela é concentrada; ligeiramente convexo e perfeitamente unido ao tórax e ao flanco.

- Flanco: pequeno, curto, cheio e em relação com a brevidade do lobo, obliqüidade e afastamento das costelas.

- Espáduas: de comprimento e largura proporcionais à cabeça, inclinadas, desenvolvidas, fortes e bem afastadas.

- Braços e codilhos: bem desenvolvidos, fortes, com excelentes aprumos.

- Antebraços: musculosos, longos, largos e fortes, bem aprumados.

- Joelhos e canela: curtos, largos e espessos, com tendões fortes, limpos e destacados.

- Boletos: secos, redondos fortes e limpos.

- Quartelas: fortes, curtas, largas, espessas, nítidas e medianamente inclinadas.

- Cascos: de volume proporcional ao corpo, duros, sólidos, aprumados e negros de preferência.

- Coxas e pernas: fortes, bem descidas, firmes, elásticas, musculosas; o ângulo tíbio-tarsiano medianamente aberto, dando por esta fora, resistência, força e andar suave.

- Jarretes: amplos, largos, fortes, secos e musculosos, paralelos ao plano médio do corpo, bem aprumados. 
- Altura: média de 1,45 m nos machos e nas fêmeas, com oscilações entre a mínima de 1,40 m e a máxima de 1,50 m.

- Tórax: média de 1,75 m com oscilações entre o mínimo de 1,68 m e o máximo de 1,80 m sempre em relação à altura.

- Peso: oscilará entre 400 e 450 quilos.

- Pelagem: de preferência gateada, moura, rosilha, alazã, zaina, escura e tordilha.

- Temperamento: vivo, ativo, inteligente, corajoso e bondoso, muito forte, bem disposto e possuidor de grande resistência.

- Aptidão: o crioulo é, por excelência, um cavalo de trabalho, ideal na lida com o gado, para passeio e enduro, podendo ser usado para percorrer grandes distâncias. [26]

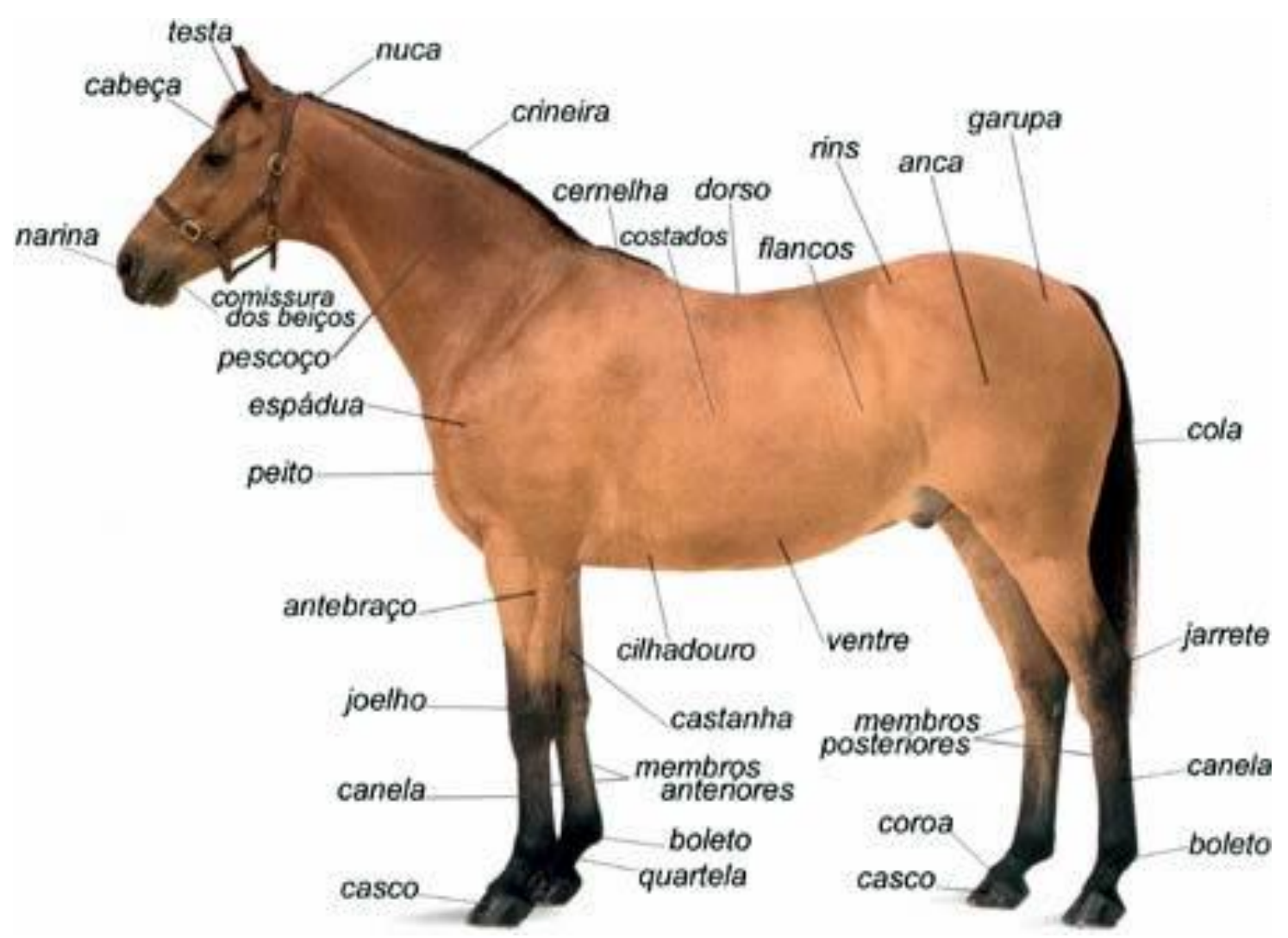

Figura 2 - Anatomia externa do cavalo. 

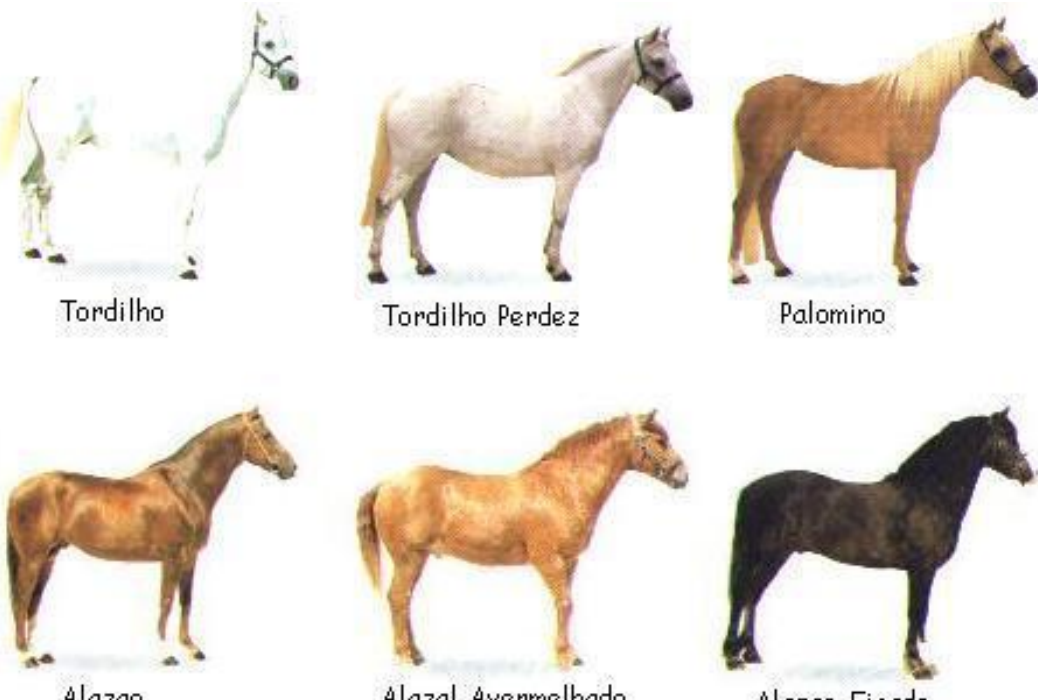

Alazal Avermelhado

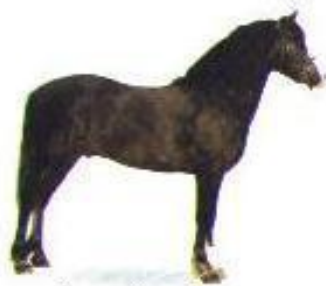

Alazao-Figado

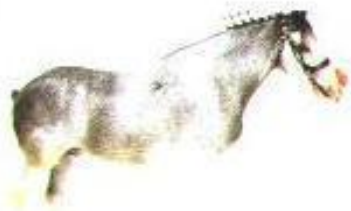

Ruao-Azulado
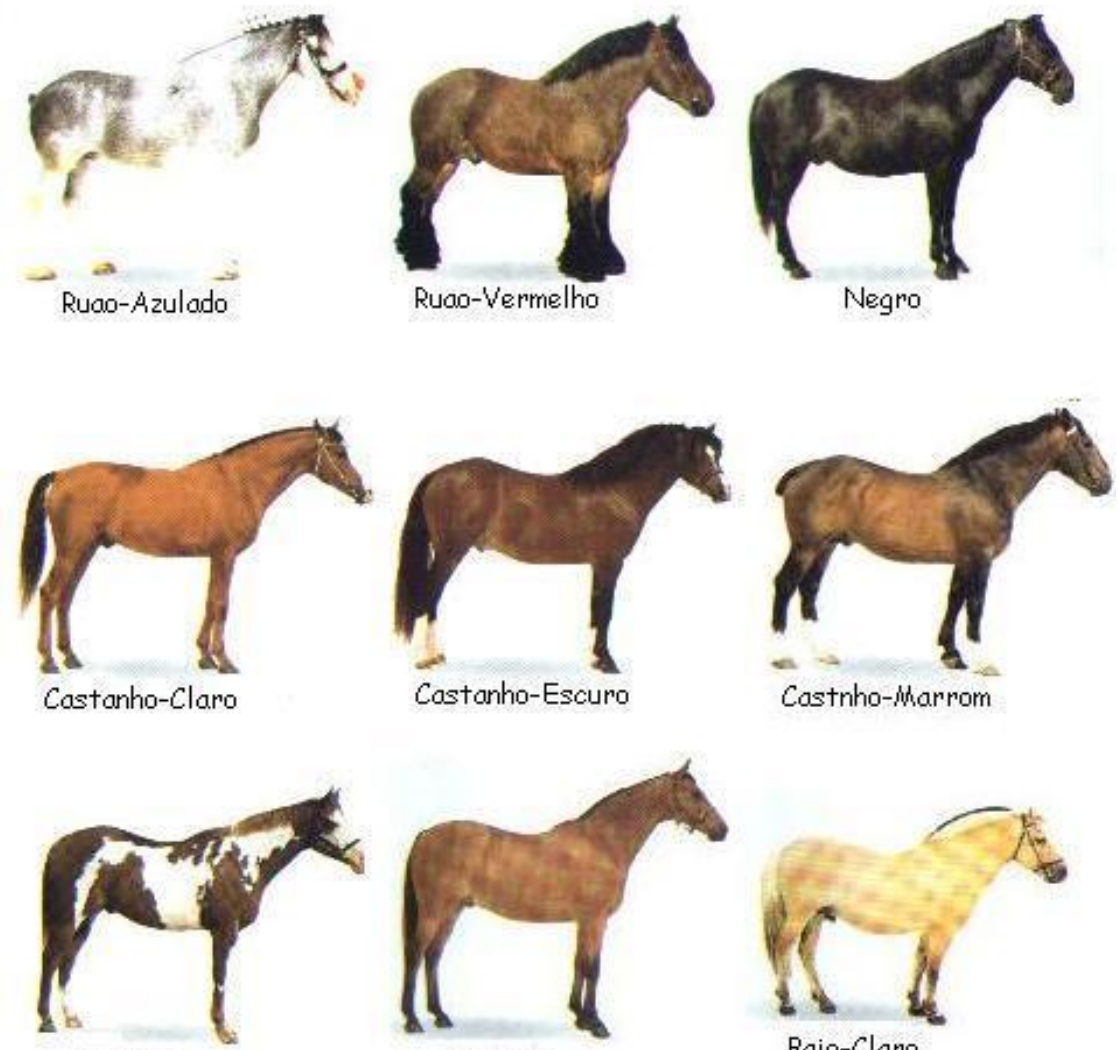

whalhado
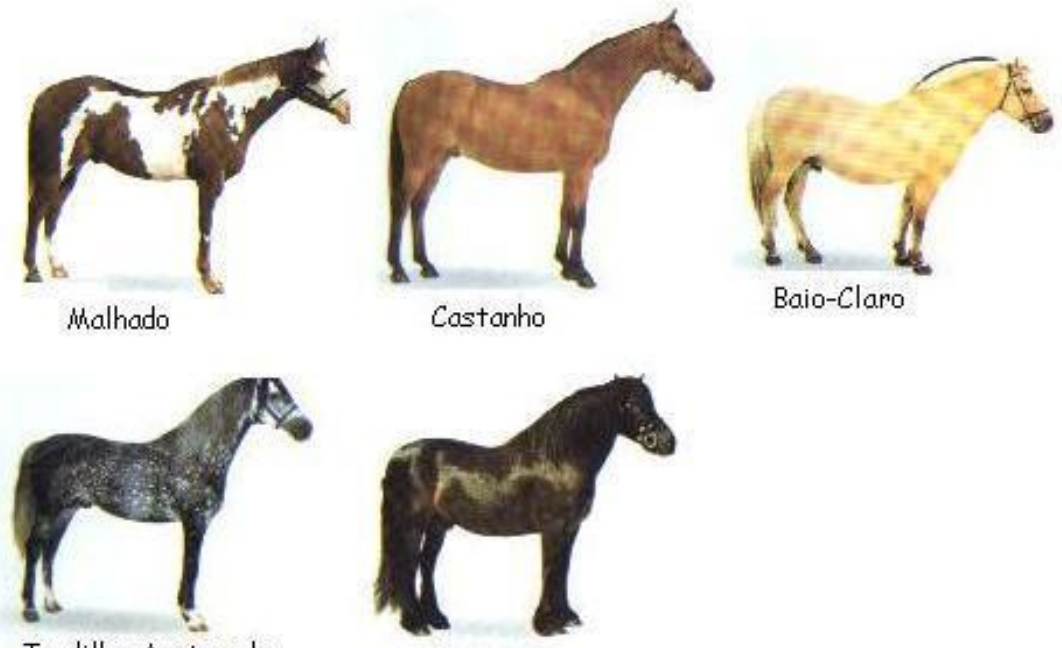

Tordilho-Apatacado

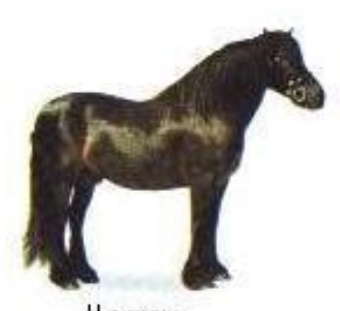

Marrom

Figura 3 - Pelagem dos cavalos. 


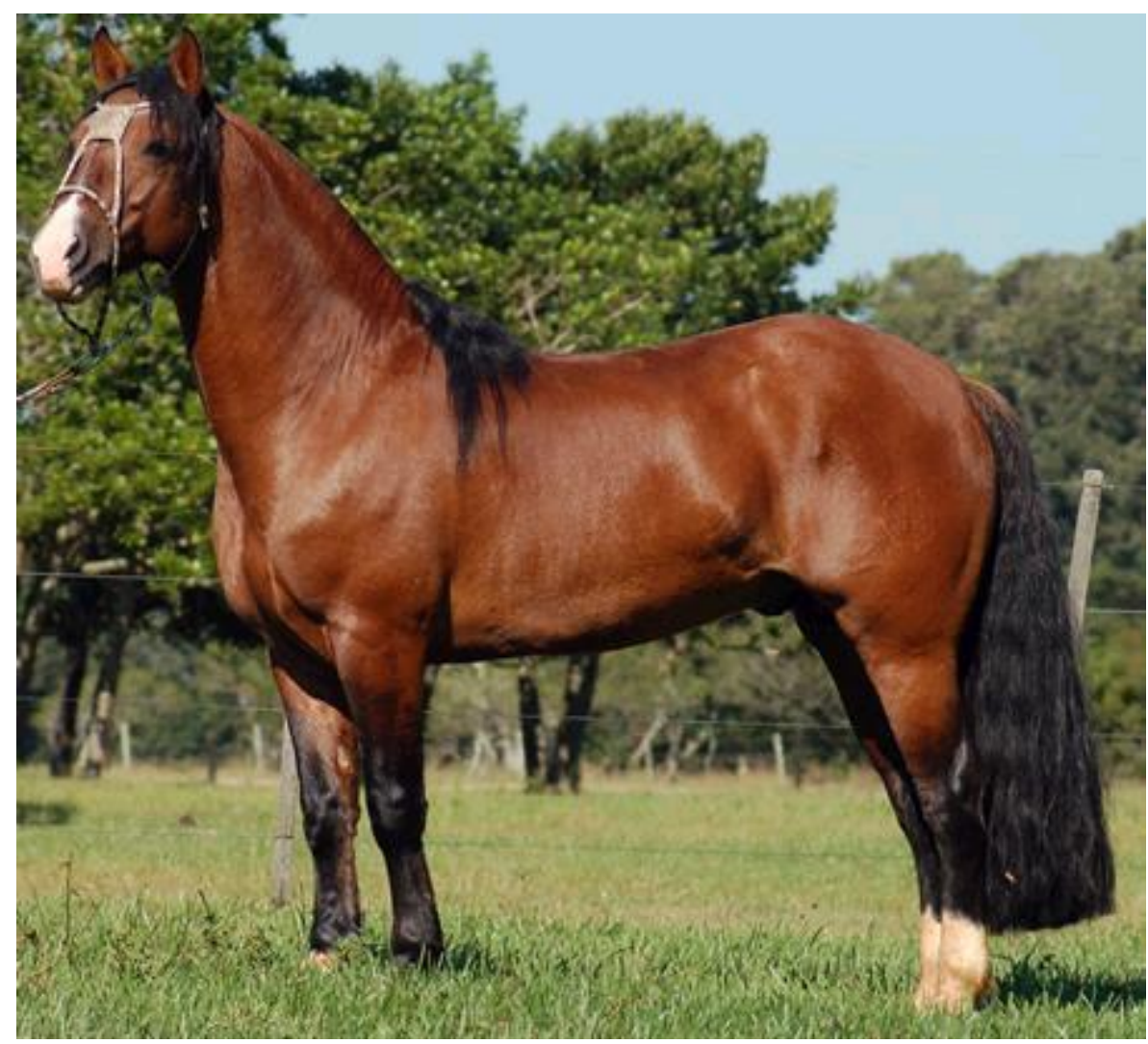

Figura 4 - Raça Crioula

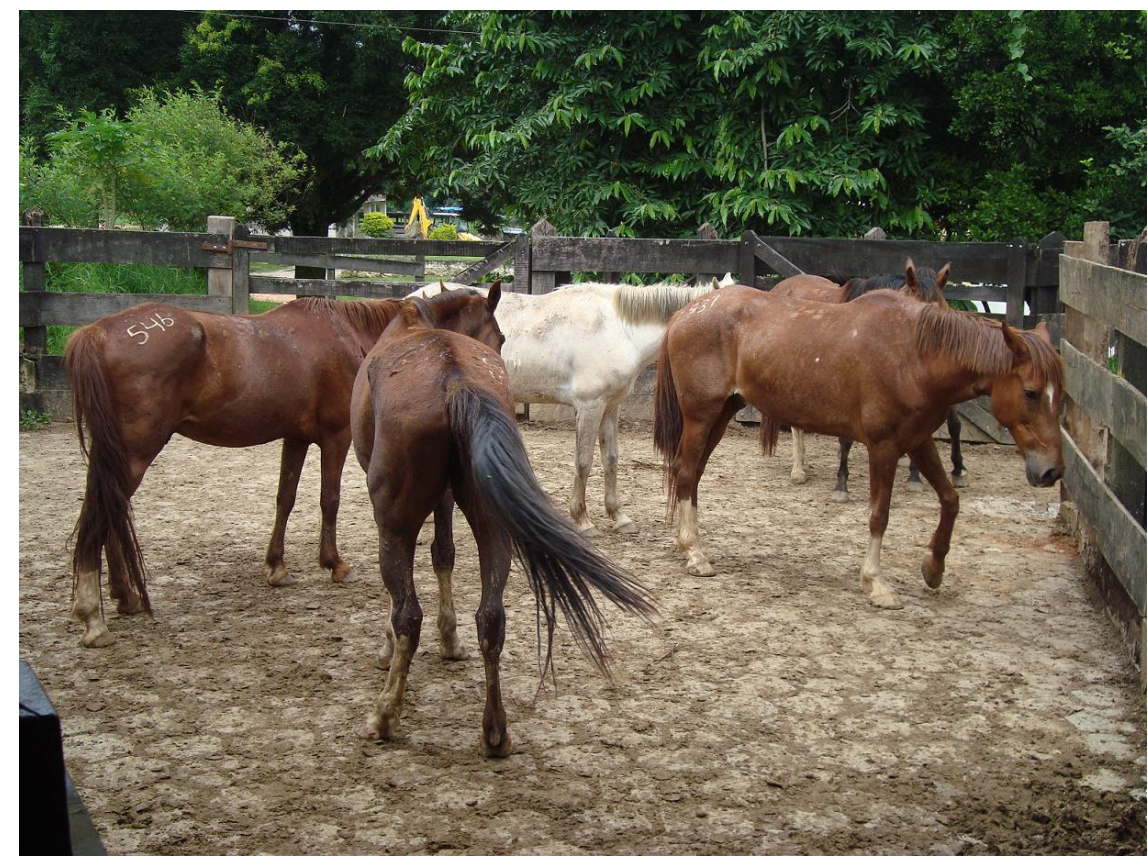

Figura 5 - Eqüinos da raça Crioula do Instituto Butantan 


\section{CAPÍTULO 3. PRODUÇÃO DE SOROS HIPERIMUNES}

\subsection{Processo de produção de soros e esquemas de imunização}

No Brasil a produção de soros hiperimunes utiliza o cavalo, como doador de plasma, imunizado com os seguintes antígenos: anatoxinas ou toxinas bacterianas, venenos de serpentes, aranhas e escorpiões de gêneros existentes no país, vírus rábico e outros [27]. Ao final de cada ciclo de imunização, os cavalos que produzem anticorpos (imunoglobulinas) com capacidade de neutralizar os antígenos utilizados na imunização são submetidos a uma sangria para obtenção do plasma hiperimune, matéria prima principal para a produção de soros hiperimunes.

Para que um soro seja eficiente na neutralização dos efeitos tóxicos de um antígeno é necessário que ele contenha anticorpos dirigidos contra sua neutralização. Dessa forma a escolha de determinados antígenos e os esquemas de imunização constituem um fator primordial para a obtenção de produtos ativos (soros eficientes) [28].

Os venenos de animais peçonhentos utilizados na imunização são mais eficientes quando administrados em determinadas doses e na presença de adjuvantes (substâncias que potencializaram a resposta imune) de forma a fazer uma melhor apresentação deste antígeno ao sistema imunológico dos cavalos.

As serpentes do gênero bothrops compreendem mais de 60 espécies encontradas em regiões da América do Norte e América do Sul. O soro antibotrópico produzido no Instituto Butantan utiliza-se de apenas alguns venenos de serpentes que representam o maior número de acidentes no Brasil. $\mathrm{O}$ antígeno utilizado para a produção é composto por uma mistura de venenos das seguintes espécies: jararaca (Bothrops jararaca), caiçaca (Bothrops moojeni), jararacussu (Bothrops jararacussu), urutu-cruzeiro (Bothrops alternatus) e jararaca pintada (Bothrops neuwiedı) [29]. 


\subsection{Cavalos utilizados na produção de soros hiperimunes do Instituto Butantan}

Atualmente o Instituto Butantan possui cerca de 800 cavalos que são utilizados para a produção de soros hiperimunes. A raça escolhida para este tipo de atividade é a raça Crioula, pois estes animais apresentam uma excelente resistência frente a atividade que executam, além de produzirem uma grande quantidade de plasma.

Quanto à nutrição, os animais recebem ração duas vezes ao dia (Equitage 22 com $22 \%$ de proteína), feno uma vez ao dia e capim a vontade. O sal é farelado e ofertado ao animal juntamente com a ração. Na Fazenda São Joaquim existe áreas adequadas (piquetes) à oferta de alimento e água.

Exames clínicos são executados periodicamente nos cavalos por veterinário da Fazenda, tais como:

1) exame clínico (visual): verificação diária da aparência física, cor da pelagem, peso do animal, casco e mucosas (indicativo de anemia);

2) exames complementares (hemograma e parasitários): somente são realizados quando se suspeita de alguma doença. Neste caso, são coletadas amostras de sangue, urina e fezes e enviados a laboratórios terceirizados. Atualmente os veterinários realizam apenas o teste de hematócritos (determinação da concentração de hemácias).

Todos os animais são vacinados contra raiva e tríplice (tétano, encefalomielite e influenza).

Quando se adquire um cavalo é obrigatória à realização do teste de anemia infecciosa. Para os outros animais que já estão inseridos na Fazenda, a realização deste teste faz-se anualmente. 


\section{CAPÍTULO 4. METODOLOGIA NUCLEAR}

O método nuclear a ser empregado denomina-se Análise por Ativação com Nêutrons. Utiliza-se feixe de nêutrons, a partir de um reator nuclear, para ativar a amostra em estudo, que induz reações nucleares nos núcleos dos elementos constituintes. Em decorrência, cada elemento (constituinte da amostra) ao tornar-se radioativo emite radiação $\gamma$ característica, processo este denominado desexcitação nuclear. A identificação dessas radiações utilizando propriedades nucleares associadas permite sua avaliação quantitativa.

\subsection{Método semi - paramétrico}

Para a utilização deste método de análise é necessário o conhecimento do fluxo de nêutrons $\left(\phi_{n}\right)$. Particularmente, para determinação do fluxo de nêutrons em reator térmico emprega-se a técnica de Razão de Cádmio [30]. A utilização deste método permite a determinação do fluxo utilizando detetores de ativação (por exemplo, folhas de ouro) por meio da relação:

$$
\phi=\frac{A^{a u} \cdot M\left(\frac{1-F_{c d}}{R_{c d}}\right)}{m \cdot N_{A} \cdot \sigma \cdot K_{t}}
$$

Onde:

$\phi \quad$ fluxo de nêutrons

$A^{a u}$ atividade de saturação do detetor de ativação (folha de Ouro)

$M \quad$ peso atômico do ouro (Au)

$N_{A} \quad$ número de Avogadro

m massa do detetor de ativação (folha de Au)

$F_{c d} \quad$ fator de Cádmio (tabelado) 
$R_{c d}$ razão obtida experimentalmente pela irradiação das folhas de $\mathrm{Au}$ (com e sem cobertura de $\mathrm{Cd}$ ).

$\sigma$ seção de choque de ativação (tabelado)

$K_{t} \quad$ fator de perturbação do fluxo (tabelado)

A medida da atividade pode ser obtida por um sistema de contagem conhecendo-se a eficiência de detecção da transição $\gamma$ de interesse usando a expressão:

$$
A=\frac{C_{\gamma} \lambda}{\varepsilon_{\gamma} I_{\gamma}\left(1-e^{-\lambda T_{i}}\right) e^{-\lambda T_{e}}\left(1-e^{-\lambda T_{c}}\right)}
$$

Onde:
A atividade do isótopo radioativo;
C $\gamma$ área da transição gama discriminada;
$\lambda \quad$ constante de desintegração (tabelado);
$\varepsilon_{\gamma} \quad$ eficiência de detecção na energia da transição gama discriminada;
$I_{\gamma} \quad$ intensidade da transição gama discriminada (tabelada);
$T_{i} \quad$ tempo de irradiação (estabelecido);
$T_{e} \quad$ tempo de espera (intervalo de tempo que decorre entre o final da irradiação e o início da contagem);
Tc tempo de contagem (estabelecido).

A partir da determinação da atividade e de fluxo de nêutrons, obtém-se a concentração dos elementos ativados, nas amostras biológicas em questão, extraindo a fração massa do isótopo radioativo [eq.3] em questão:

$$
F=\frac{\lambda \cdot M \cdot C_{\gamma} \cdot e^{\lambda \cdot T_{e}}}{m \cdot N_{A} \cdot \varepsilon_{\gamma} \cdot \sigma \cdot \phi \cdot I_{\gamma} \cdot\left(1-e^{-\lambda \cdot T_{i}}\right) \cdot\left(1-e^{-\lambda \cdot T_{c}}\right)}
$$




\subsection{Método Instrumental}

Neste método, a amostra e padrão são irradiados simultaneamente, garantindo as mesmas condições. Desta forma, as concentrações dos elementos na amostra são obtidas a partir das concentrações estabelecidas no padrão:

$$
\begin{aligned}
& A_{\text {amostra }}=\sigma \phi \frac{N_{A} m_{\text {amostra }} f}{M}\left(1-e^{-\lambda T i}\right) \\
& A_{\text {padrão }}=\sigma \phi \frac{N_{A} m_{\text {padrão }} f}{M}\left(1-e^{-\lambda T i}\right)
\end{aligned}
$$

Dividindo a equação (4) pela equação (5) obtém-se:

$$
\frac{A_{\text {amostra }}}{A_{\text {padrão }}}=\frac{m_{\text {amostra }}}{m_{\text {padrão }}}
$$

ou

$$
m_{\text {amostra }}=\frac{A_{\text {amostra }}}{A_{\text {padrão }}} \cdot m_{\text {padrão }}
$$

A partir da atividade da amostra pode-se calcular a concentração do elemento, inserindo um fator de correção devido à diferença de tempo entre a medida do padrão e da amostra, conforme a equação 4.

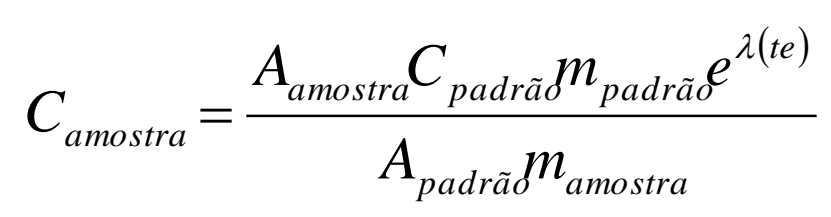

Onde: 
$C_{\text {amostra }} \quad$ concentração do elemento na amostra

$A_{\text {amostra }} \quad$ taxa de contagem da amostra

$C_{\text {padrão }} \quad$ concentração do elemento no padrão

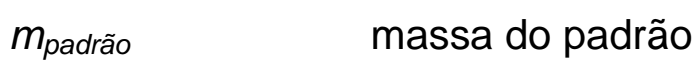

$T_{e} \quad$ tempo de espera (entre o término da irradiação e início de contagem)

$A_{\text {padrão } \quad \text { taxa de contagem do padrão }}$

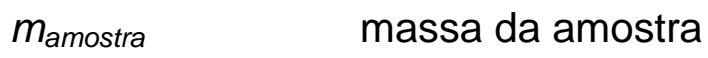




\section{CAPÍTULO 5. INSTRUMENTAÇÃO NUCLEAR}

A instrumentação nuclear utilizada na aquisição dos espectros da radiação $\gamma$ é constituída por um espectrômetro $\gamma$, eletrônica associada e sistema de aquisição de dados descritos a seguir. A Figura 6 ilustra o instrumental nuclear utilizado no LEER.

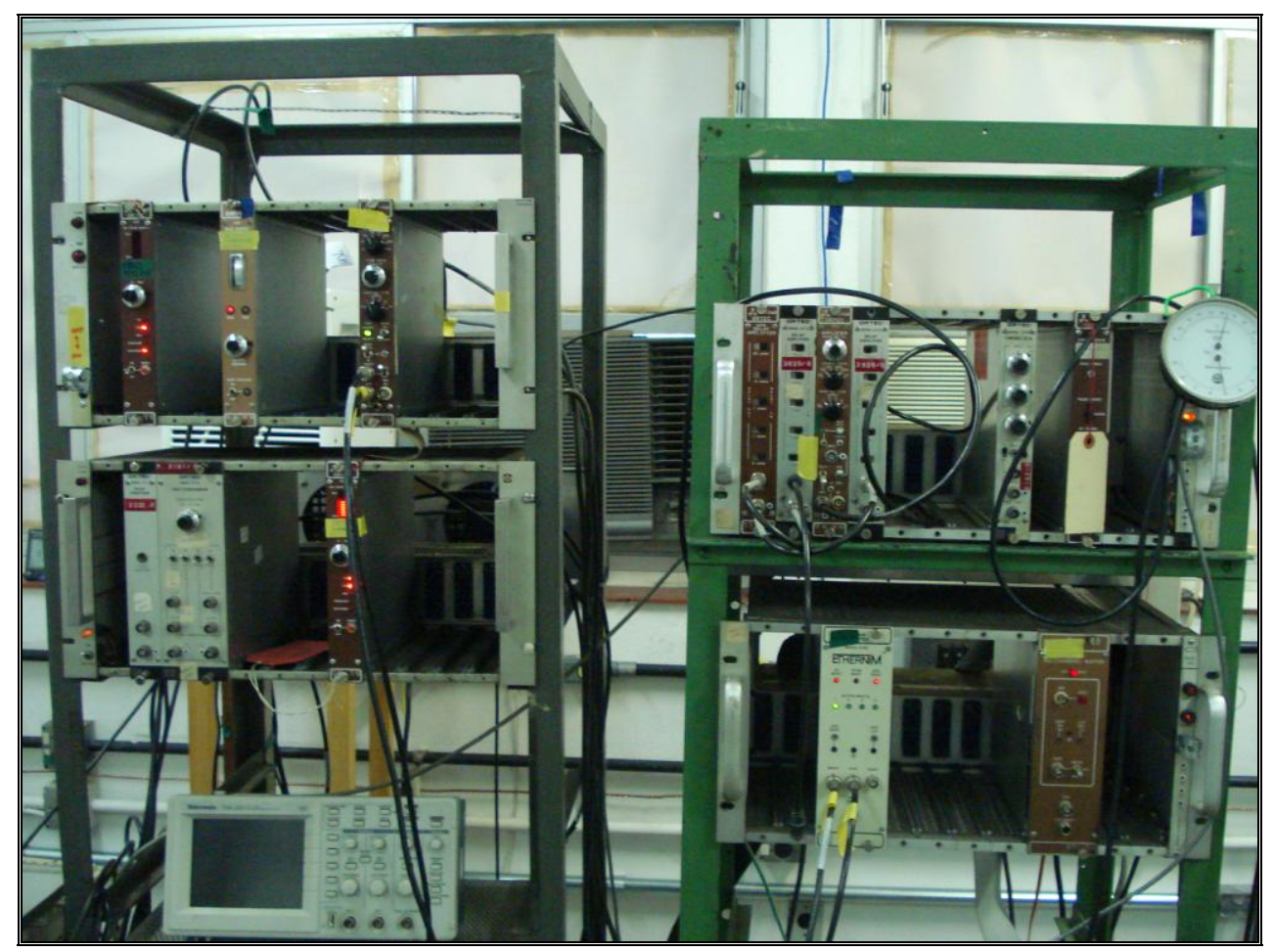

Figura 6 - Instrumentação nuclear utilizada no LEER.

O espectrômetro $\gamma$ é constituído por um detetor semicondutor de Germânio hiperpuro (HPGe) montado no interior de uma blindagem de chumbo. Este tipo de blindagem minimiza a radiação de fundo do laboratório. Um suporte circular de lucite, centralizado sobre a face do detetor, sustenta a amostra (Figura 7). 


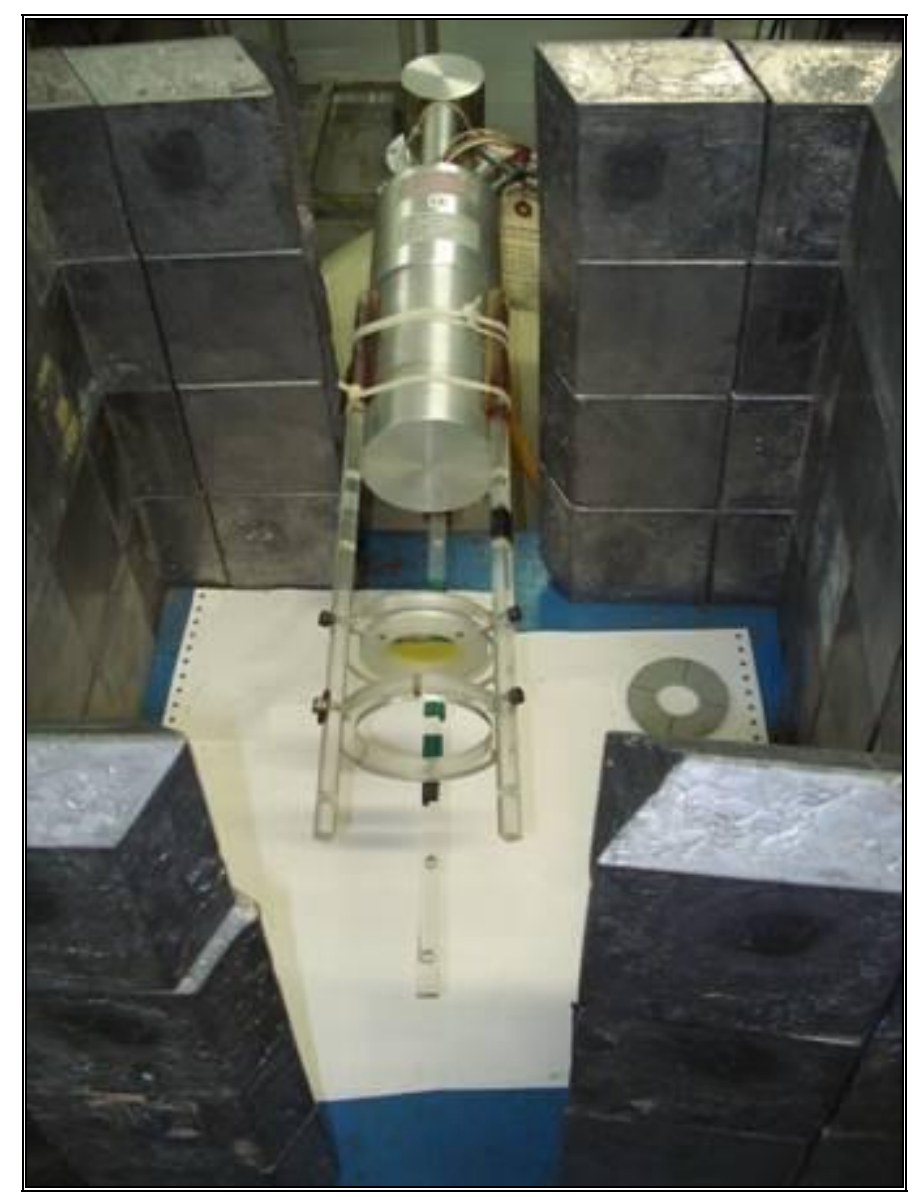

Figura 7 - Arranjo com detector de germânio hiperpuro (HPGe).

O sistema de aquisição de dados consiste de um amplificador linear, e um multicanal ADCAM, (ORTEC-918-A) controlado por um microcomputador PC. Na Figura 8 é apresentado um diagrama ilustrativo da instrumentação utilizada.

Para a realização deste estudo o espectrômetro foi calibrado em energia e eficiência utilizando-se fontes padrão [31]. 


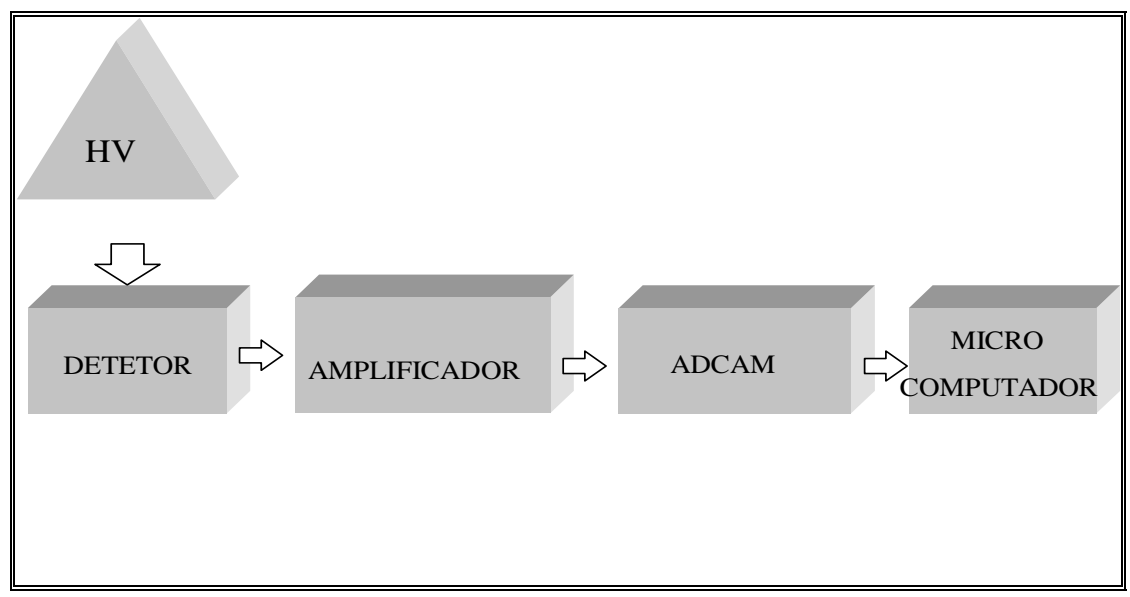

Figura 8 - Esquema simplificado do arranjo eletrônico utilizado. 


\section{CAPÍTULO 6. PROCEDIMENTO EXPERIMENTAL}

\subsection{Calibração do Espectrômetro $\gamma$}

Para a obtenção da curva de calibração em energia do espectrômetro $\mathrm{Y}$, utiliza-se fontes padrão [25] de: ${ }^{60} \mathrm{Co},{ }^{109} \mathrm{Cd},{ }^{133} \mathrm{Ba},{ }^{137} \mathrm{Cs}$ e ${ }^{152} \mathrm{Eu}$, para que se possa associar a posição dos fotopicos dos padrões, ao longo dos 4096 canais e suas respectivas energias.

A calibração de eficiência do detetor foi obtida a partir dos dados das seguintes fontes padrão de ${ }^{152} \mathrm{Eu}$ e ${ }^{57} \mathrm{Co}$, que possuem valores de intensidade obtidas na compilação da IAEA [31]. A curva obtida é apresentada na Figura 9 e a função é dada por:

$$
\varepsilon(E)=a \cdot e^{b . E}+c \cdot e^{d \cdot E}
$$

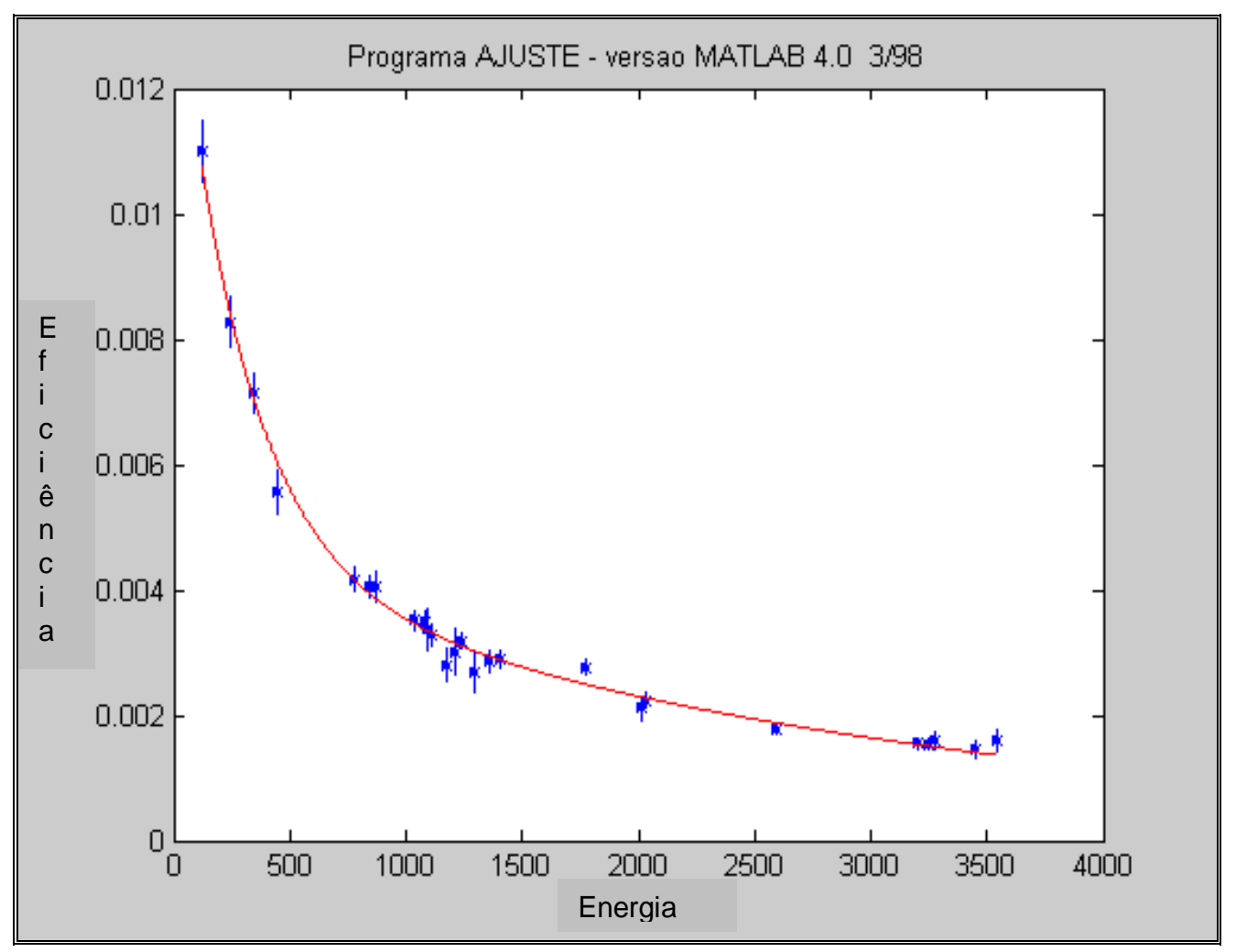

Figura 9 - Função ajustada (em vermelho) e eficiência de fotopico experimental (azul) 


\subsection{Coleta e Preparo das Amostras}

Para a obtenção da padronização das análises de sangue foram coletadas amostras de sangue total de 20 cavalos não imunizados (8 machos e 12 fêmeas), sadios, na faixa etária de 1 a 3 anos e peso médio de $350 \mathrm{~kg}$, compondo o GRUPO CONTROLE (GC) apresentado em detalhes na Tabela 1. Foram colhidas amostras de sangue total ( $2 \mathrm{ml})$, na ausência de qualquer tipo de anticoagulante (tubo seco). Imediatamente após a coleta, parte do sangue total $(100 \mu \mathrm{L})$ foi transferido para papel de filtro (Whatman $\mathrm{N}^{\circ} 41$ ) e submetido a secagem por alguns minutos, utilizando-se uma lâmpada infravermelha. Outra alíquota $(500 \mu \mathrm{L})$ foi transferida para um cilindro plástico (eppendorf) e exposta à secagem por alguns minutos. Todas as amostras (100 e $500 \mu \mathrm{L}$ ) foram preparadas em duplicata.

Tabela 1 - Descrição do GRUPO CONTROLE (GC)

\begin{tabular}{ccc}
\hline $\begin{array}{c}\text { IDENTIFICAÇÃO } \\
\text { DO ANIMAL }\end{array}$ & SEXO & IDADE \\
\hline $\mathbf{2 6 5}$ & MASCULINO & 2 anos \\
$\mathbf{1 4 4}$ & FEMININO & 2 anos \\
$\mathbf{2 6 4}$ & FEMININO & 2 anos \\
$\mathbf{4 0}$ & FEMININO & 1 ano \\
$\mathbf{1 2 4}$ & MASCULINO & 1 ano \\
$\mathbf{1 2 7}$ & FEMININO & 2 anos \\
$\mathbf{2 7 6}$ & FEMININO & 2 anos \\
$\mathbf{8 5}$ & MASCULINO & 1 ano \\
$\mathbf{2 6 7}$ & FEMININO & 2 anos \\
$\mathbf{1 0 2}$ & MASCULINO & 2 anos \\
$\mathbf{8 6}$ & FEMININO & 3 anos \\
$\mathbf{4 7 2}$ & FEMININO & 2 anos \\
$\mathbf{4 7 1}$ & FEMININO & 2 anos \\
$\mathbf{2 3 7}$ & FEMININO & 2 anos \\
$\mathbf{4 7 3}$ & MASCULINO & 2 anos \\
$\mathbf{1 7 4}$ & FEMININO & 2 anos \\
$\mathbf{5 6}$ & MASCULINO & 3 anos \\
$\mathbf{7 0}$ & FEMININO & 2 anos \\
$\mathbf{1 5 5}$ & MASCULINO & 2 anos \\
$\mathbf{1 3 2}$ & MASCULINO & 2 anos \\
& &
\end{tabular}


Em paralelo foram coletadas amostras de sangue do grupo de cavalos machos RECÉM IMUNIZADOS (GI), mesma faixa etária e peso, imediatamente após o primeiro ciclo de imunização.

Todos os animais (GC e GI) foram submetidos às mesmas condições de oferta de alimento e ao mesmo procedimento de coleta de sangue.

\subsection{Avaliação da dieta dos eqüinos}

Nesta investigação estudos complementares foram realizados via metodologia nuclear (AAN): análise multielementar da ração e do sal fornecido como suplemento alimentar. A finalidade dessas medidas teve por objetivo dar suporte a interpretação das análises dos minerais no sangue dos cavalos (tanto no grupo controle como imunizado), pois desequilíbrios minerais, tais como: absorção, interações com outros elementos, absorção maior que a eliminação (intoxicação) e eliminação maior que a absorção, devem-se principalmente a composição mineral na dieta dos animais.

Para as análises da ração foram coletados pellets de peso aproximado de 250 a $270 \mathrm{mg}$. Para análise do sal foram coletadas amostras de 100 a $250 \mathrm{mg}$ de sal granulado.

\subsection{Avaliação do soro antibotrópico produzido no Instituto Butantan}

Estudos complementares foram realizados, via metodologia nuclear (AAN), no soro antibotrópico produzido no Instituto Butantan com o objetivo avaliar se os elementos inorgânicos presentes no produto final determinados via metodologia nuclear eram compatíveis com os valores obtidos via metodologia convencional (Titulometria) utilizada pela Seção de Controle de Qualidade do Instituto Butantan (SP-Brasil).

Para esta análise foram utilizadas alíquotas de (100 - $500 \mu \mathrm{L})$, de soro antibotrópico (antiveneno), preparadas conforme descrito no item 6.2. 


\subsection{Irradiação utilizando o método semi - paramétrico de AAN}

Cada amostra biológica $(100 \mu \mathrm{L}$ de sangue), juntamente com 0 detetores de nêutrons (duas folhas de Au de $<1 \mathrm{mg}$ ) foi irradiada por 2 minutos no reator IEA-R1 do IPEN permitindo a ativação simultânea destes materiais. Desta forma obtêm-se os espectros de raios $\gamma$ tanto para o cálculo do fluxo de nêutrons como para a obtenção da concentração dos elementos ativados, nas mesmas condições de irradiação. Este procedimento permite determinar simultaneamente a concentração dos elementos $\mathrm{Br}, \mathrm{Ca}, \mathrm{Cl}, \mathrm{I}, \mathrm{K}, \mathrm{Mg}, \mathrm{Na}, \mathrm{P}, \mathrm{S}$ e Zn. Procedimento análogo foi adotado para as alíquotas de $500 \mu \mathrm{L}$ de sangue, para determinação de Fe sendo o tempo de irradiação de 4 horas. Particularmente, os elementos $\mathrm{Br}$, Ca e Zn foram avaliados por irradiação curta (IC) e longa (IL) (Tabela 2).

Após a irradiação, os detetores de nêutrons foram submetidos à contagem no espectrômetro - $\gamma$ permitindo a identificação e cálculo da área da transição gama de $411 \mathrm{keV}$ do ${ }^{197} \mathrm{Au}$ para determinação do fluxo de nêutrons. Da mesma forma, cada amostra biológica foi submetida à contagem no espectrômetro- $\gamma$, permitindo a identificação e cálculo das áreas das transições $\gamma$ de interesse (Tabela 2). Esses espectros de raios $\gamma$ foram analisados utilizando-se o programa IDF [32].

De posse do valor do fluxo de nêutrons e da área da transição $\gamma$ de interesse obteve-se a concentração de elementos ativados nas amostras de sangue utilizando um software ATIVAÇÃO desenvolvido por MEDEIROS e outros [33].

\subsection{Irradiação utilizando o método Instrumental de AAN}

As amostras biológicas foram irradiadas por 4 minutos juntas com 0 padrão (músculo bovino - NIST 8414 e de sangue AIEA A-13). Após a ativação foram feitas aquisições de 5 minutos para o padrão e na seqüência para a 
amostra. O cálculo da área foi realizado utilizando o software IDF e o cálculo da concentração utilizando a equação (8).

Na Figura 10 é apresentada uma síntese do procedimento experimental.

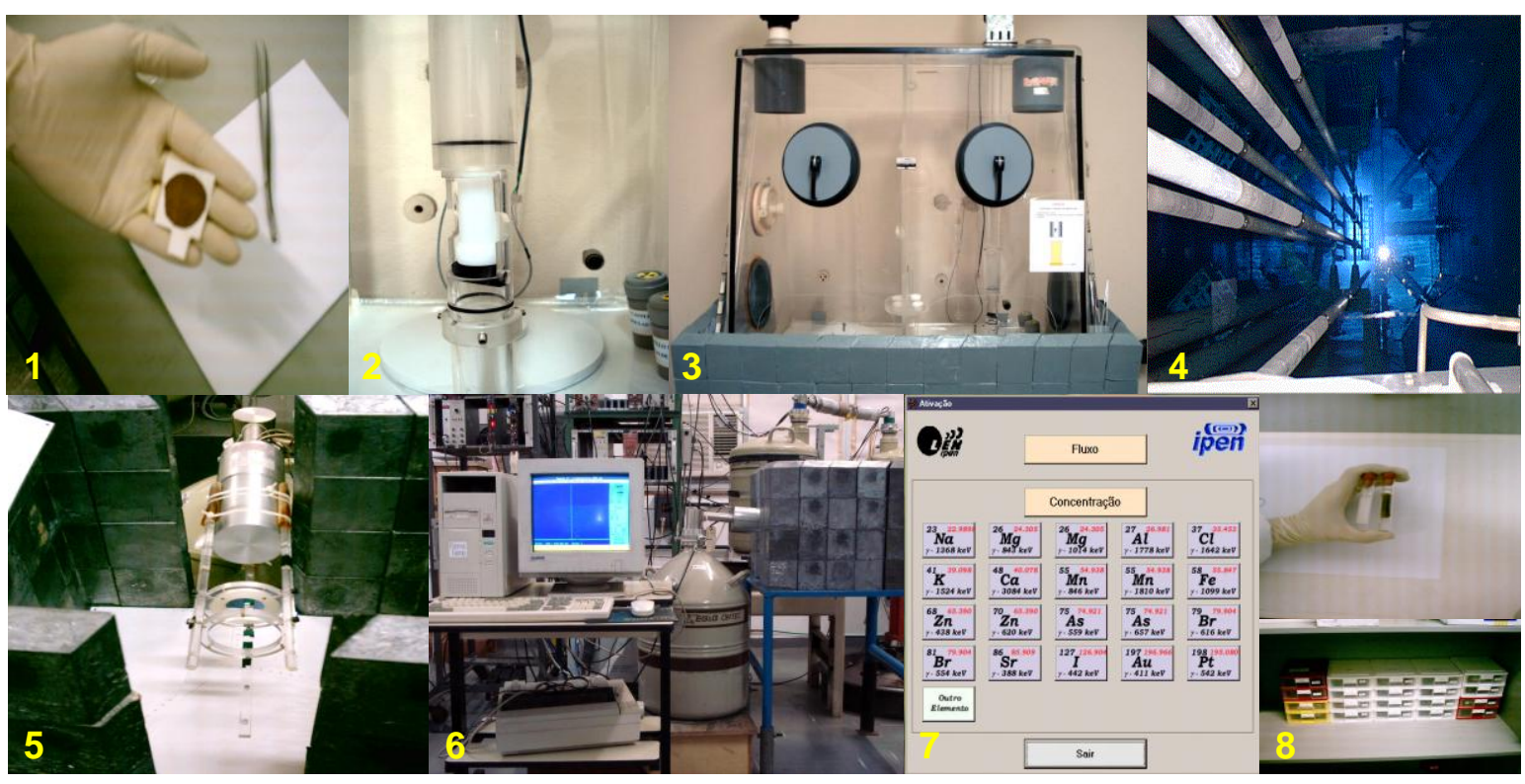

Figura 10 - Etapas do procedimento experimental: 1) Preparo da amostra em papel utilizando $100 \mu \mathrm{L}$ de sangue total; 2) Invólucro de irradiação onde a amostra biológica é acondicionada; 3) Estação pneumática de irradiação; 4) Reator de pesquisa IEA - R1; 5) Detector de germânio hiperpuro; 6) Instrumentação Nuclear; 7) Software Ativação; 8) Acondicionamento das amostras biológicas após irradiação. 
Tabela 2 - Propriedades nucleares relacionadas a seus isótopos: composição isotópica (\%); isótopo a ser ativado; reação induzida por nêutrons $(n, \gamma)$; energia dos raios $\gamma$ emitidos $\left(E_{\gamma}\right)$ e a meia vida $\left(T_{1 / 2}\right)$ associada ao isótopo ativado.

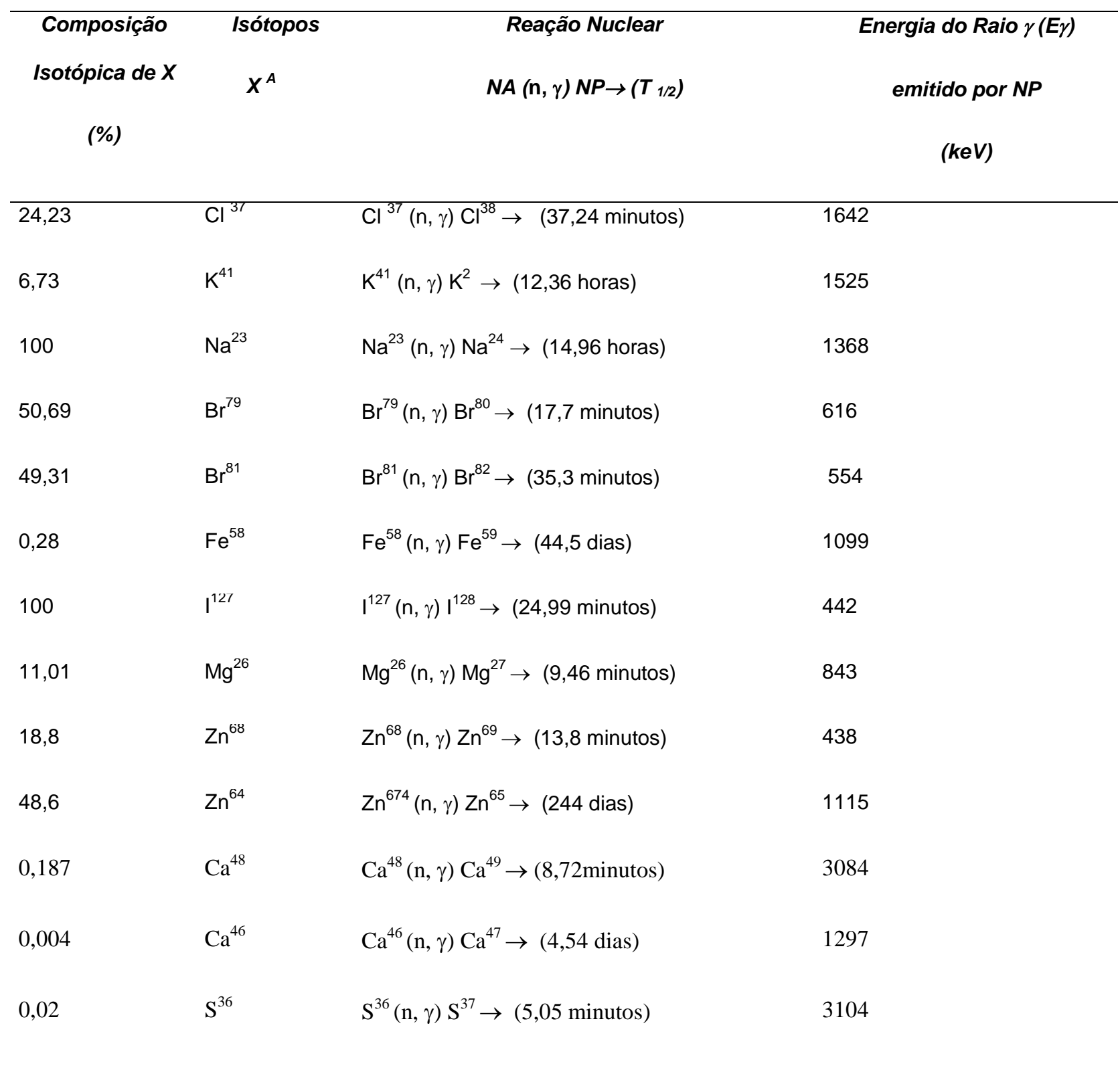

A : é $n^{\circ}$ de massa

$X:$ elemento químico

NA: núcleo alvo (sangue)

NP: núcleo produzido após o bombardeio com nêutrons térmicos (sangue radioativo)

$T_{1 / 2}$ : meia vida (tempo necessário para que a taxa de emissão de raios $\gamma$ decaiam a metade). 


\subsection{Material de referência}

Para verificar o desempenho do método de AAN e do aparato experimental foram realizadas análises em materiais de referência de: Músculo Bovino (NIST 8414), Soro Humano (Dried Human Serum), Soro Humano (ICP04S-06) e Sangue Humano (ICP-01B-03). Alíquotas de $250 \mathrm{mg}$ foram usadas para amostras sólidas (NIST 8414 e Dried Human Serum) e alíquotas de 100 $\mu \mathrm{L}$ para amostras líquidas (ICP-04S-06 e ICP-01B-03). Foram realizadas sete medidas para cada padrão e o valor médio obtido para a concentração dos elementos é apresentado na Tabela 3.

Tabela 3. Resultados da AAN comparado com os valores certificados.

\begin{tabular}{|c|c|c|c|}
\hline Elemento & Valor certificado & Presente estudo & $\mid$ Z score $\mid$ \\
\hline $\mathrm{Br}, \mathrm{gL}^{-1}$ & ${ }^{(2)} 0,044 \pm 0,013$ & $0,049 \pm 0,017$ & 0,4 \\
\hline $\mathrm{Ca}, \mathrm{g} \mathrm{kg}^{-1}$ & $\begin{array}{l}{ }^{(1)} 0,145 \pm 0,020 \\
{ }^{(2)} 0,161 \pm 0,013\end{array}$ & $\begin{array}{l}0,132 \pm 0,014 \\
0,153 \pm 0,048\end{array}$ & $\begin{array}{l}0,6 \\
0,6\end{array}$ \\
\hline $\mathrm{Cl}, \%$ & $\begin{array}{l}{ }^{(1)} 0,188 \pm 0,015 \\
{ }^{(3)} 0,338 \pm 0,016\end{array}$ & $\begin{array}{l}0,202 \pm 0,013 \\
0,343 \pm 0,015\end{array}$ & $\begin{array}{l}0,9 \\
0,3\end{array}$ \\
\hline $\mathrm{K}$ & $\begin{array}{l}\text { (1) } 15,17 \pm 0,37 \mathrm{gkg}^{-1} \\
\text { (3) } 0,15 \pm 0,01 \mathrm{gL}^{-1} \\
\text { (4) } 1,82 \pm 0,11 \mathrm{gL}^{-1}\end{array}$ & $\begin{array}{c}14,76 \pm 1,04 \mathrm{gkg}^{-1} \\
0,17 \pm 0,02 \mathrm{gL}^{-1} \\
1,61 \pm 0,28 \mathrm{gL}^{-1}\end{array}$ & $\begin{array}{l}1,1 \\
2,0 \\
1,9\end{array}$ \\
\hline $\mathrm{Na}$ & $\begin{array}{l}\text { (1) } 2,10 \pm 0,08 \mathrm{gkg}^{-1} \\
\text { (3) } 3,10 \pm 0,17 \mathrm{gL}^{-1} \\
\text { (4) } 1,85 \pm 0,09 \mathrm{gL}^{-1}\end{array}$ & $\begin{array}{l}2,11 \pm 0,10 \mathrm{gkg}^{-1} \\
3,18 \pm 0,06 \mathrm{gL}^{-1} \\
1,77 \pm 0,29 \mathrm{gL}^{-1}\end{array}$ & $\begin{array}{l}0,1 \\
0,5 \\
0,9\end{array}$ \\
\hline
\end{tabular}

\footnotetext{
(1) NIST 8414 - Músculo Bovino

(2) Material de referência biológico de segunda geração [34]

(3) ICP-04S-06 - Soro humano

(4) ICP-01B-03 - Sangue humano
} 
Os resultados apresentados na Tabela 3 mostraram que os dados são compatíveis dentro de $\pm 2 \mathrm{DP}(Z$ score $<2)$, evidenciando 0 adequado funcionamento do aparato experimental e o bom desempenho da metodologia nuclear. 


\section{CAPÍTULO 7. RESULTADOS}

O tratamento estatístico aplicado à análise de dados envolveu a determinação da média aritmética, desvio padrão, mediana, moda, valor máximo, valor mínimo e valores de referência (intervalo de referência). A apresentação desses resultados além de uniformizar 0 tratamento dos dados permitiu a comparação entre os grupos investigados (GC e Gl).

$\mathrm{Na}$ Figura 11 é apresentado o espectro parcial de raios gama da amostra de sangue (alíquota de $100-500 \mu \mathrm{L}$ de sangue total) irradiadas no Reator IEA - R1 num fluxo da ordem de $10^{11} \mathrm{n} \cdot \mathrm{cm}^{-2} \cdot \mathrm{s}^{-1}$ e na Tabela 4 é apresentado um quadro que sintetiza os resultados dos elementos investigados no sangue total de eqüinos do grupo controle (GC).

Para ilustrar, na Figura 12 estão dispostos os resultados obtidos para a concentração de $\mathrm{Br}, \mathrm{Ca}, \mathrm{Cl}, \mathrm{Fe}, \mathrm{I}, \mathrm{K}, \mathrm{Mg}, \mathrm{Na}, \mathrm{S}, \mathrm{P}$ e $\mathrm{Zn}$ para o grupo controle $(\mathrm{GC})$, onde o intervalo de referência obtido no presente estudo foi incluído considerando-se \pm 1 e \pm 2 DP (Desvio Padrão) e na Figura 13 para o grupo recém imunizado (Gl) considerando o intervalo de referência ( $\pm 1 \mathrm{DP}$ e $\pm 2 \mathrm{DP})$, obtido no presente estudo, para grupo controle (constituído por machos).

Na Tabela 5 estão dispostos os resultados obtidos para a concentração dos elementos investigados no sangue de eqüinos dos grupos: grupo controle (GC) e grupo imunizado (Gl).

As informações a respeito das relações prioritárias que governam cada processo biológico para o grupo controle (Tabela 6) foi obtidas por meio da análise das correlações [35] entre os elementos medidos em sangue (Anexo 5).

Na Figura 14 é apresentado o espectro de raios gama da amostra da ração analisada e na Tabela 7 um comparativo entre as análises feitas pela técnica de Análise por Ativação com Nêutrons e as informações do fabricante da ração. 
$\mathrm{Na}$ Tabela 8 é apresentado um comparativo entre as análises feitas pela técnica de Análise por Ativação com Nêutrons e as informações do fabricante do sal.

$\mathrm{Na}$ Tabela 9 é apresentado um comparativo entre as análises feitas pela técnica de Ativação com Nêutrons e Titulométrica referente a composição de elementos inorgânicos presentes no soro antibotrópico (antiveneno). 

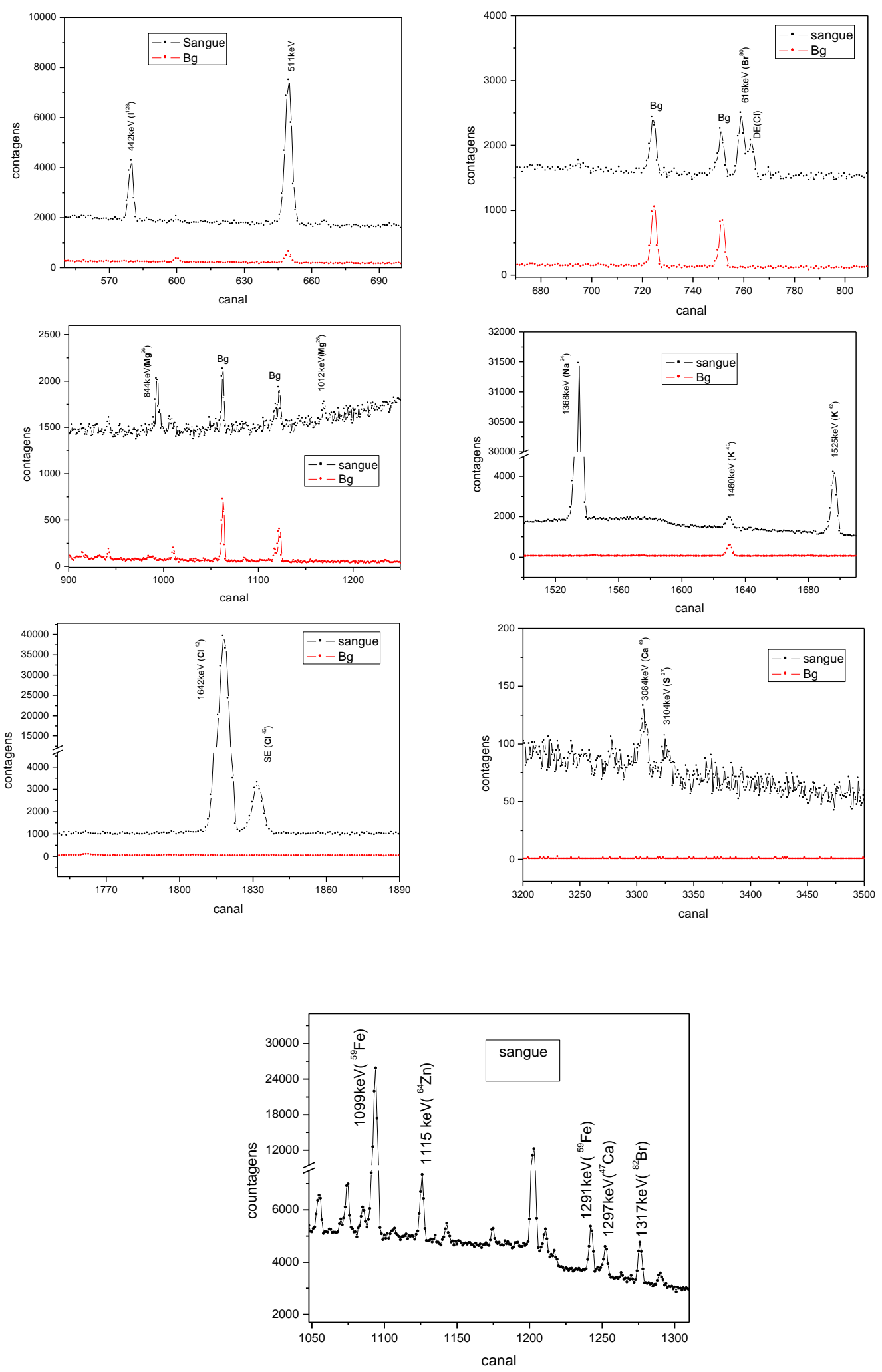

Figura 11 - Espectro parcial de raios gama de sangue total de eqüino (GC), utilizando detetor de HPGe. 
Tabela 4 - Concentração dos elementos investigados no sangue de eqüinos (GC).

\begin{tabular}{|c|c|c|c|c|c|}
\hline $\begin{array}{c}\text { Elementos, } \\
\mathrm{gL}^{-1}\end{array}$ & Media & $\pm 1 \mathrm{DP}$ & $\begin{array}{c}\text { Valor } \\
\text { mínimo }\end{array}$ & $\begin{array}{c}\text { Valor } \\
\text { máximo }\end{array}$ & $\begin{array}{l}\text { Valores de } \\
\text { Referência * }\end{array}$ \\
\hline \multirow[t]{3}{*}{$\mathrm{Cl}$} & 2,68 & 0,29 & 2,07 & 3,12 & $2,10-3,26$ \\
\hline & $2,80^{m}$ & 0,19 & & & \\
\hline & $2,61^{f}$ & 0,33 & & & \\
\hline \multirow[t]{3}{*}{$\mathbf{K}$} & 1,94 & 0,40 & 1,21 & 2,75 & $1,14-2,74$ \\
\hline & $1,70^{\mathrm{m}}$ & 0,36 & & & \\
\hline & $2,10^{f}$ & 0,36 & & & \\
\hline \multirow[t]{3}{*}{$\mathrm{Na}$} & 2,08 & 0,36 & 1,61 & 2,88 & $1,36-2,80$ \\
\hline & $2,22^{m}$ & 0,40 & & & \\
\hline & $1,99^{f}$ & 0,32 & & & \\
\hline \multirow[t]{3}{*}{$\mathrm{Ca}$} & 0,229 & 0,070 & 0,135 & 0,415 & $0,089-0,369$ \\
\hline & $0,211^{m}$ & 0,034 & & & \\
\hline & $0,240^{f}$ & 0,085 & & & \\
\hline \multirow[t]{3}{*}{$\mathbf{M g}$} & 0,052 & 0,011 & 0,034 & 0,071 & $0,030-0,074$ \\
\hline & $0,046^{m}$ & 0,007 & & & \\
\hline & $0,056^{f}$ & 0,012 & & & \\
\hline \multirow[t]{3}{*}{$\mathbf{I}$} & 0,00142 & 0,00062 & 0,00044 & 0,00273 & $0,00018-0,00266$ \\
\hline & 0,00132 & 0,00065 & & & \\
\hline & 0,00150 & 0,00062 & & & \\
\hline
\end{tabular}




\begin{tabular}{|c|c|c|c|c|c|}
\hline \multirow[t]{3}{*}{ Fe } & 0,535 & 0,077 & 0,368 & 0,708 & $0,381-0,689$ \\
\hline & $0,498^{m}$ & 0,070 & & & \\
\hline & $0,568^{f}$ & 0,071 & & & \\
\hline \multirow[t]{3}{*}{$\mathrm{Br}$} & 0,0032 & 0,0012 & 0,0017 & 0,0070 & $0,0008-0,0056$ \\
\hline & $0,0028^{m}$ & 0,0006 & & & \\
\hline & $0,0035^{f}$ & 0,0014 & & & \\
\hline \multirow[t]{3}{*}{ Zn } & 0,0030 & 0,0009 & 0,0017 & 0,0052 & $0,0012-0,0048$ \\
\hline & $0,0028^{m}$ & 0,0006 & & & \\
\hline & $0,0032^{f}$ & 0,0011 & & & \\
\hline \multirow[t]{3}{*}{$\mathbf{S}$} & 1,89 & 0,45 & 1,12 & 2,64 & $0,99-2,79$ \\
\hline & $1,95^{\mathrm{m}}$ & 0,49 & & & \\
\hline & $1,85^{f}$ & 0,44 & & & \\
\hline \multirow[t]{3}{*}{$\mathbf{P}$} & 0,81 & 0,59 & 0,26 & 2,18 & $<1,99$ \\
\hline & $0,72^{\mathrm{m}}$ & 0,50 & & & \\
\hline & $0,88^{f}$ & 0,66 & & & \\
\hline
\end{tabular}

\footnotetext{
* considerando intervalo de confiabilidade $95 \%$ usualmente adotado na prática clínica

m: machos

f: fêmeas
} 

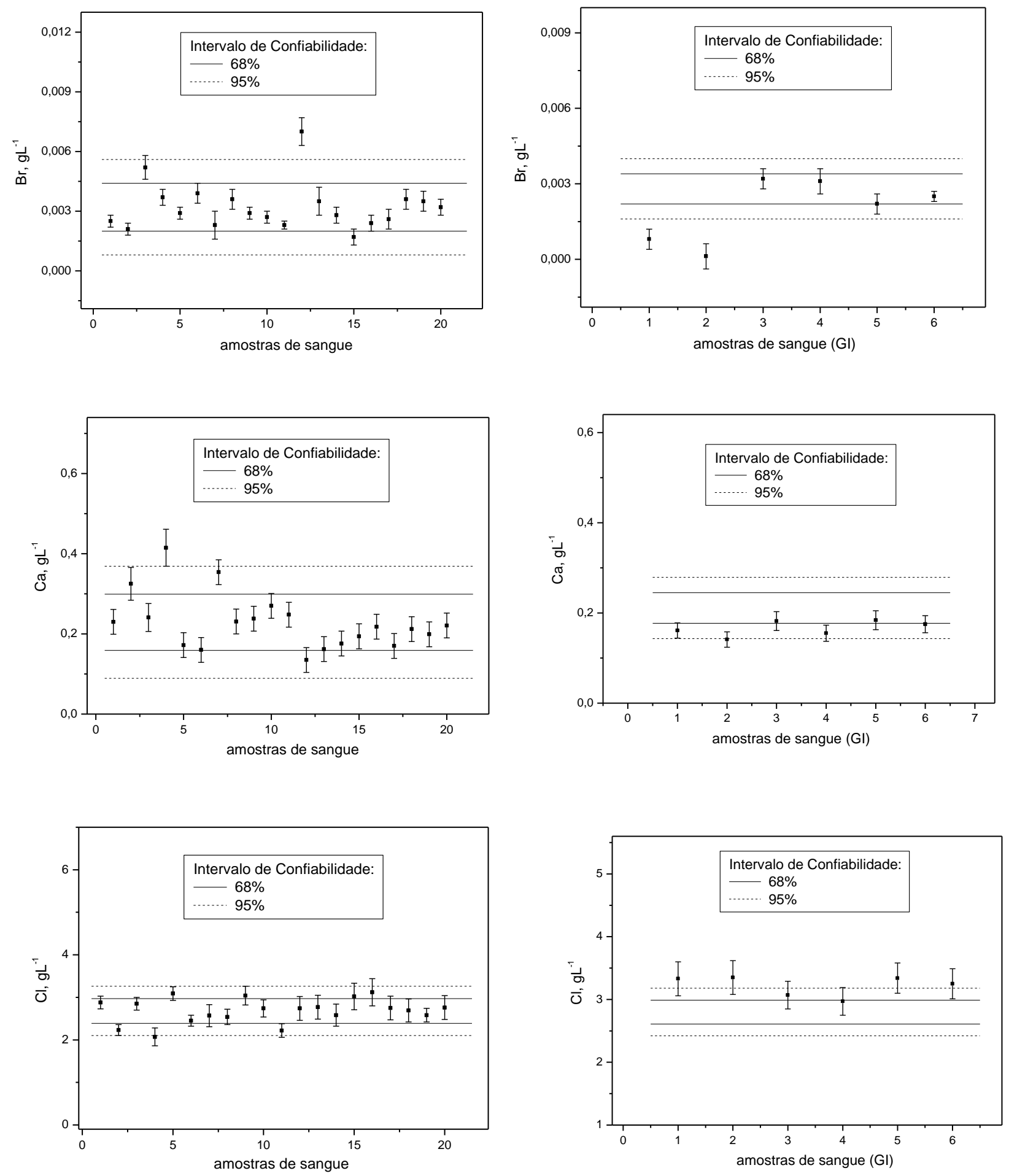

Figura 12 - Concentração em GC

Figura 13 - Concentração em GI 

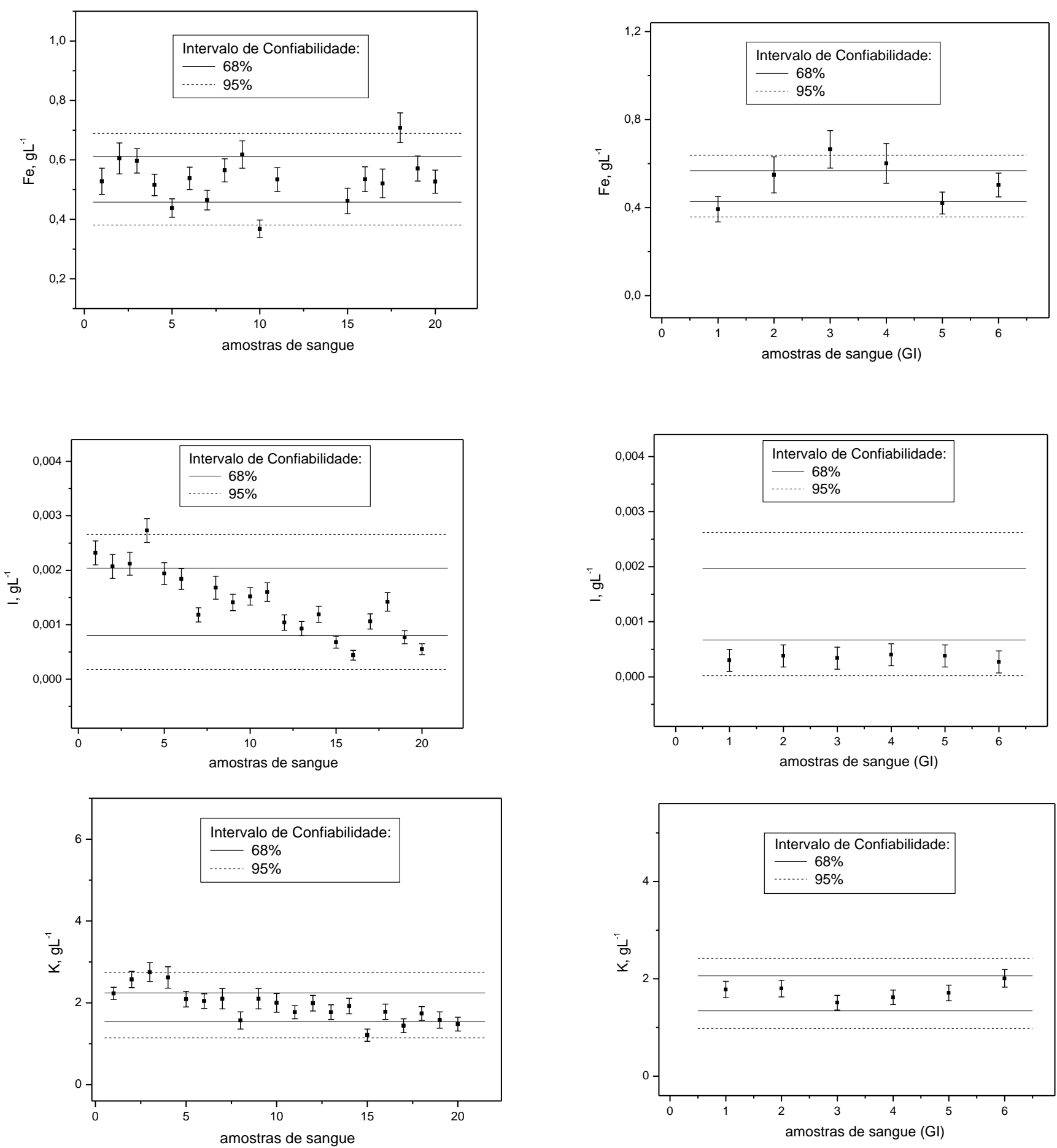

Figura 12 - Concentração em GC 

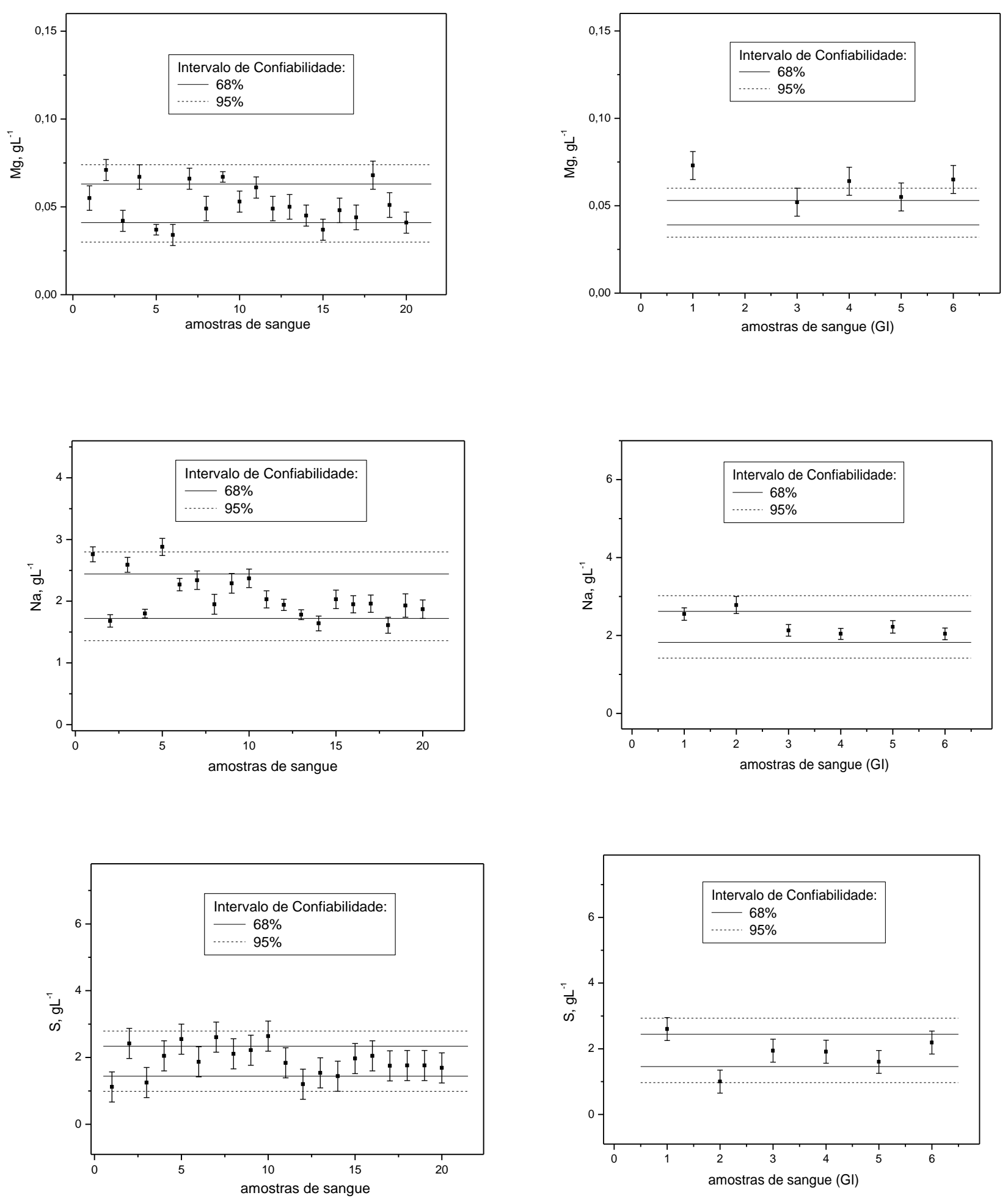

Figura 12 - Concentração em GC

Figura 13 - Concentração em GI 

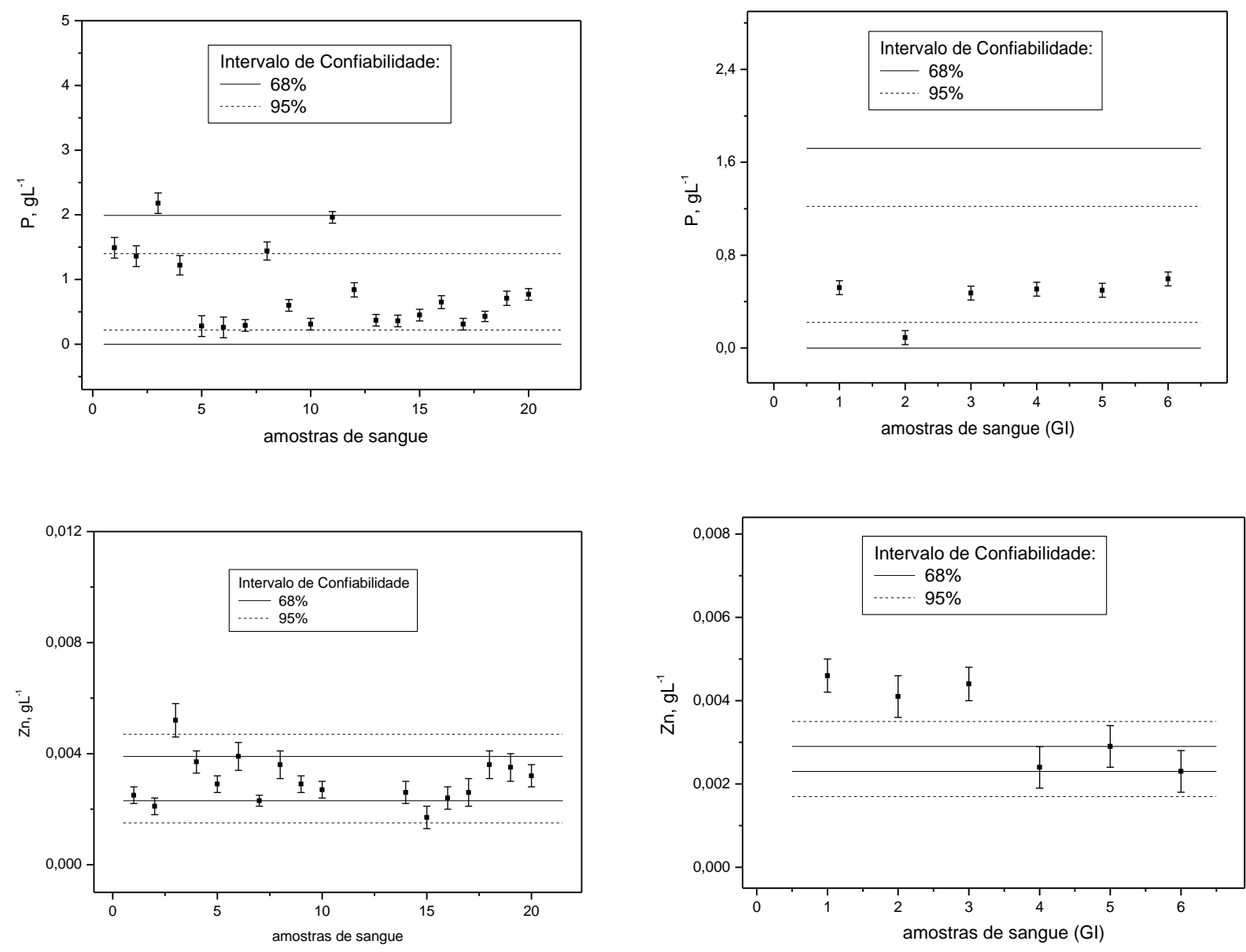

Figura 12 - Concentração em GC

Figura 13 - Concentração em GI 
Tabela 5 - Concentração de $\mathrm{Na}, \mathrm{K}, \mathrm{Cl}, \mathrm{Ca}, \mathrm{P}, \mathrm{Mg}, \mathrm{Br}, \mathrm{S}, \mathrm{I}, \mathrm{Fe}$ e $\mathrm{Zn}$ investigados no sangue de equinos nos grupos CG (constituídos por machos) e Gl.

\begin{tabular}{|c|c|c|c|c|c|}
\hline $\mathrm{Na}, \mathrm{gL}^{-1}$ & Média & $\pm 1 \mathrm{DP}$ & Mediana & $\begin{array}{l}\text { Valor } \\
\text { mínimo }\end{array}$ & $\begin{array}{c}\text { Valor } \\
\text { máximo }\end{array}$ \\
\hline $\begin{array}{c}\mathrm{GC} \\
n=8 \\
{[1,42-3,02]^{a}}\end{array}$ & 2,22 & 0,40 & 2,00 & 1,87 & 2,88 \\
\hline $\begin{array}{c}\mathrm{Gl} \\
n=6 \\
{[1,70-\mathbf{2 , 9 0}]^{\mathrm{a}}}\end{array}$ & 2,30 & 0,30 & 2,18 & 2,04 & 2,78 \\
\hline $\mathrm{K}, \mathrm{gL}-1$ & Média & $\pm 1 \mathrm{DP}$ & Mediana & $\begin{array}{l}\text { Valor } \\
\text { mínimo }\end{array}$ & $\begin{array}{l}\text { Valor } \\
\text { máximo }\end{array}$ \\
\hline $\begin{array}{c}C G \\
n=8 \\
{[0,98-2,42]^{a}}\end{array}$ & 1,70 & 0,36 & 1,58 & 1,21 & 2,23 \\
\hline $\begin{array}{c}\text { Gl } \\
n=6 \\
{[1,40-\mathbf{2}, 08]^{a}}\end{array}$ & 1,74 & 0,17 & 1,75 & 1,51 & 2,01 \\
\hline Cl, gL-1 & Média & $\pm 1 \mathrm{DP}$ & Mediana & $\begin{array}{l}\text { Valor } \\
\text { mínimo }\end{array}$ & $\begin{array}{c}\text { Valor } \\
\text { máximo }\end{array}$ \\
\hline $\begin{array}{c}\mathrm{GC} \\
n=8 \\
{[2,42-3,18]^{a}}\end{array}$ & 2,80 & 0,19 & 2,76 & 2,54 & 3,09 \\
\hline $\begin{array}{c}\mathrm{Gl} \\
n=6 \\
{[2,90-3,54]^{a}}\end{array}$ & 3,22 & 0,16 & 3,29 & 2,97 & 3,35 \\
\hline $\mathrm{Ca}, \mathrm{gL}-1$ & Média & $\pm 1 \mathrm{DP}$ & Mediana & $\begin{array}{l}\text { Valor } \\
\text { mínimo }\end{array}$ & $\begin{array}{c}\text { Valor } \\
\text { máximo }\end{array}$ \\
\hline $\begin{array}{c}\mathrm{GC} \\
n=8 \\
{[0,143-0,279]^{a}}\end{array}$ & 0,211 & 0,034 & 0,210 & 0,170 & 0,270 \\
\hline $\begin{array}{c}\mathrm{Gl} \\
\mathrm{n}=6 \\
{[0,132-\mathbf{0 , 2 0 0}]^{\mathrm{a}}}\end{array}$ & 0,166 & 0,017 & 0,168 & 0,141 & 0,184 \\
\hline
\end{tabular}

$n$ : número de amostras analisadas

a : intervalo de confiabilidade de $95 \%$ usualmente empregado em clinica. 


\begin{tabular}{|c|c|c|c|c|c|}
\hline $\mathbf{P}, \mathrm{gL}^{-1}$ & Média & $\pm 1 \mathrm{DP}$ & Mediana & $\begin{array}{l}\text { Valor } \\
\text { mínimo }\end{array}$ & $\begin{array}{l}\text { Valor } \\
\text { máximo }\end{array}$ \\
\hline $\begin{array}{c}\mathrm{GC} \\
n=8 \\
{[<1,5]^{a}}\end{array}$ & 0,72 & 0,50 & 0,58 & 0,28 & 1,49 \\
\hline $\begin{array}{c}\mathrm{Gl} \\
n=6 \\
{[0,09-\mathbf{0 , 8 1}]^{\mathrm{a}}}\end{array}$ & 0,45 & 0,18 & 0,50 & 0,09 & 0,60 \\
\hline$M g, g L-1$ & Média & $\pm 1 \mathrm{DP}$ & Mediana & $\begin{array}{l}\text { Valor } \\
\text { mínimo }\end{array}$ & $\begin{array}{l}\text { Valor } \\
\text { máximo }\end{array}$ \\
\hline $\begin{array}{c}\mathrm{GC} \\
\mathrm{n}=8 \\
{[0,032-0,060]^{\mathrm{a}}}\end{array}$ & 0,046 & 0,007 & 0,047 & 0,037 & 0,055 \\
\hline $\begin{array}{c}G I \\
n=5 \\
{[0,010-0,114]^{a}}\end{array}$ & 0,062 & 0,026 & 0,064 & 0,052 & 0,073 \\
\hline $\mathrm{Br}, \mathrm{gL}-1$ & Média & $\pm 1 \mathrm{DP}$ & Mediana & $\begin{array}{l}\text { Valor } \\
\text { mínimo }\end{array}$ & $\begin{array}{c}\text { Valor } \\
\text { máximo }\end{array}$ \\
\hline $\begin{array}{c}G C \\
n=8 \\
{[0,0016-0,0040]^{a}}\end{array}$ & 0,0028 & 0,0006 & 0,0028 & 0,0017 & 0,0036 \\
\hline $\begin{array}{c}\text { Gl } \\
n=6 \\
{[<0,0039]^{a}}\end{array}$ & 0,0020 & 0,0013 & 0,0024 & 0,0001 & 0,0032 \\
\hline $\mathrm{S}, \mathrm{gL}-1$ & Média & $\pm 1 \mathrm{DP}$ & Mediana & $\begin{array}{l}\text { Valor } \\
\text { mínimo }\end{array}$ & $\begin{array}{l}\text { Valor } \\
\text { máximo }\end{array}$ \\
\hline $\begin{array}{c}\mathrm{GC} \\
\mathrm{n}=8 \\
{[0,97-2,93]^{\mathrm{a}}}\end{array}$ & 1,95 & 0,49 & 1,87 & 1,12 & 2,64 \\
\hline $\begin{array}{c}\mathrm{Gl} \\
\mathrm{n}=6 \\
{[0,79-\mathbf{2 , 9 5}]^{\mathrm{a}}}\end{array}$ & 1,87 & 0,54 & 1,93 & 1,00 & 2,60 \\
\hline
\end{tabular}

$n$ : número de amostras analisadas

${ }^{a}$ : intervalo de confiabilidade de $95 \%$ usualmente empregado em clinica . 


\begin{tabular}{|c|c|c|c|c|c|}
\hline I, mgL-1 & Média & $\pm 1 \mathrm{DP}$ & Mediana & $\begin{array}{l}\text { Valor } \\
\text { mínimo }\end{array}$ & $\begin{array}{l}\text { Valor } \\
\text { máximo }\end{array}$ \\
\hline $\begin{array}{c}\mathrm{GC} \\
\mathrm{n}=8 \\
{[0, \mathbf{1}-\mathbf{2 , 5}]^{\mathrm{a}}}\end{array}$ & 1,3 & 0,6 & 1,3 & 0,6 & 2,3 \\
\hline $\begin{array}{c}\text { Gl } \\
n=6 \\
{[0, \mathbf{0}-\mathbf{0 , 5}]^{a}}\end{array}$ & 0,3 & 0,1 & 0,4 & 0,3 & 0,4 \\
\hline $\mathrm{Fe}, \mathrm{gL}-1$ & Média & $\pm 1 \mathrm{DP}$ & Mediana & $\begin{array}{c}\text { Valor } \\
\text { mínimo }\end{array}$ & $\begin{array}{l}\text { Valor } \\
\text { máximo }\end{array}$ \\
\hline $\begin{array}{c}\mathrm{GC} \\
n=8 \\
{[0,358-0,638]^{a}}\end{array}$ & 0,498 & 0,070 & 0,524 & 0,368 & 0,571 \\
\hline $\begin{array}{c}\text { Gl } \\
n=6 \\
{[0,312-\mathbf{0 , 7 3 2}]^{a}}\end{array}$ & 0,522 & 0,105 & 0,526 & 0,393 & 0,665 \\
\hline Zn, mgL-1 & Média & $\pm 1 \mathrm{DP}$ & Mediana & $\begin{array}{l}\text { Valor } \\
\text { mínimo }\end{array}$ & $\begin{array}{l}\text { Valor } \\
\text { máximo }\end{array}$ \\
\hline $\begin{array}{c}\mathrm{GC} \\
\mathrm{n}=8 \\
{[\mathbf{1 , 6 - 4 , 0}]^{\mathrm{a}}}\end{array}$ & 2,8 & 0,6 & 2,7 & 1,7 & 3,6 \\
\hline $\begin{array}{c}\text { Gl } \\
n=6 \\
{[\mathbf{1 , 5 - 5 , 5}]^{a}}\end{array}$ & 3,5 & 1,0 & 3,5 & 2,3 & 4,6 \\
\hline
\end{tabular}

$n$ : número de amostras analisadas

a : intervalo de confiabilidade de $95 \%$ usualmente empregado em clinica. 
Tabela 6 - Matriz de correlação para os elementos determinados em sangue total para o grupo controle (GC); as relações prioritárias encontram-se em destaque.

\begin{tabular}{|c|c|c|c|c|c|c|c|c|c|c|c|}
\hline & $\mathrm{Br}$ & $\mathrm{Ca}$ & $\mathrm{Cl}$ & I & $\mathrm{K}$ & $\mathrm{Mg}$ & $\mathrm{Na}$ & $\mathrm{S}$ & $\mathrm{Fe}$ & $\mathrm{Zn}$ & $\mathbf{P}$ \\
\hline $\mathrm{Br}$ & 1 & $-0,28$ & $-0,03$ & 0,10 & 0,26 & $-0,17$ & $-0,02$ & $-0,51$ & 0,39 & 0,87 & 0,19 \\
\hline $\mathrm{Ca}$ & & 1 & $-0,53$ & 0,49 & 0,53 & 0,68 & $-0,03$ & 0,47 & $-0,07$ & $-0,06$ & 0,33 \\
\hline $\mathrm{Cl}$ & & & 1 & $-0,45$ & $-0,30$ & $-0,45$ & 0,44 & $-0,08$ & $-0,14$ & $-0,12$ & $-0,34$ \\
\hline I & & & & 1 & 0,77 & 0,31 & 0,36 & 0,06 & 0,07 & 0,35 & 0,49 \\
\hline $\mathbf{K}$ & & & & & 1 & 0,38 & 0,32 & 0,04 & 0,12 & 0,38 & 0,44 \\
\hline Mg & & & & & & 1 & $-0,28$ & 0,27 & 0,38 & $-0,19$ & 0,22 \\
\hline $\mathrm{Na}$ & & & & & & & 1 & 0,12 & $-0,46$ & 0,10 & 0,11 \\
\hline$S$ & & & & & & & & 1 & $-0,44$ & $-0,41$ & $-0,33$ \\
\hline $\mathrm{Fe}$ & & & & & & & & & 1 & 0,39 & 0,32 \\
\hline $\mathrm{Zn}$ & & & & & & & & & & 1 & 0,31 \\
\hline $\mathbf{P}$ & & & & & & & & & & & 1 \\
\hline
\end{tabular}



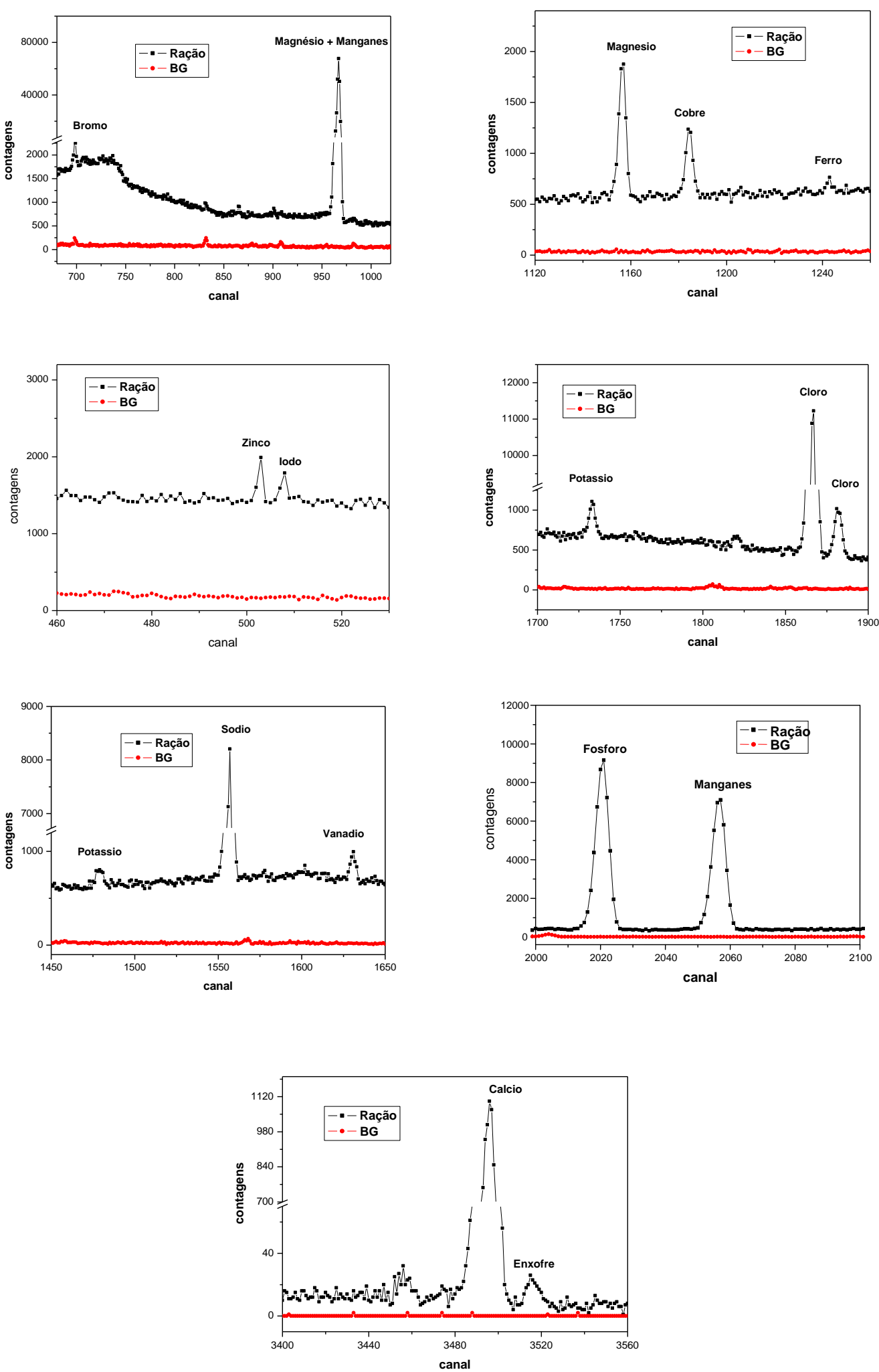

Figura 14 - Espectros dos elementos contidos na ração 
Tabela 7 - Concentração dos minerais na ração.

\begin{tabular}{|c|c|c|}
\hline Elementos & $\begin{array}{c}\text { Concentração }\left(\mathrm{mgkg}^{-1}\right) \\
\text { Presente estudo } \\
\text { AAN }\end{array}$ & $\begin{array}{c}\text { Concentração (mgkg }{ }^{-1} \text { ) } \\
\text { Dados do fabricante }^{\star}\end{array}$ \\
\hline Zinco & 2300 & 21,22 \\
\hline lodo & 0,8 & 1 \\
\hline Brometos & 1,9 & ne \\
\hline Magnésio & 4400 & 0,19 \\
\hline Cobre & 7,6 & 15,24 \\
\hline Sódio & 3200 & 0,19 \\
\hline Potássio & 14000 & ne \\
\hline Cloretos & 72000 & ne \\
\hline Fósforo & 46000 & 0,5 \\
\hline Manganês & 260 & 17,4 \\
\hline Cálcio & 12000 & 2 \\
\hline Vanádio & 0,42 & ne \\
\hline Enxofre & 40 & 0,21 \\
\hline
\end{tabular}

ne : não especificado pelo fabricante

(a): valor médio

* especificação correspondente ao mínimo exigida 
Tabela 8 - Concentração dos minerais no sal.

\section{$\begin{array}{lll}\text { ELEMENTOS CONCENTRAÇÃO } & \text { DADOS DO FABRICANTE }\end{array}$}

\begin{tabular}{ccc}
\hline $\mathbf{M g}$ & $0,013 \pm 0,003 \mathrm{gkg}^{-1}$ & $10 \mathrm{gkg}^{-1}$ \\
$\mathbf{C l}$ & $129 \pm 5 \mathrm{gkg}^{-1}$ & ne \\
$\mathbf{P}$ & $12,0 \pm 0,5 \mathrm{gkg}^{-1}$ & $80 \mathrm{gkg}^{-1}($ mínimo $)$ \\
$\mathbf{C a}$ & $155 \pm 7 \mathrm{gkg}^{-1}$ & $160 \mathrm{gkg}^{-1}($ máximo $)$ \\
$\mathrm{Na}$ & $82,3 \pm 9,2 \mathrm{gkg}^{-1}$ & $100 \mathrm{gkg}^{-1}$ \\
I & $8,3 \pm 0,5 \mathrm{mgkg}^{-1}$ & $10 \mathrm{mgkg}^{-1}$ \\
V & $0,69 \pm 0,02 \mathrm{mgkg}^{-1}$ & $\mathrm{ne}$ \\
\hline
\end{tabular}

ne : não especificado pelo fabricante

Tabela 9 - Concentração dos minerais no soro antibotrópico (antiveneno).

\begin{tabular}{cccccc}
\hline $\begin{array}{c}\text { Soro } \\
\text { (antiveneno) }\end{array}$ & $\mathbf{V M}$ & $\mathbf{\pm 1 D P}$ & $\mathbf{V}_{\text {Min }}$ & $\mathbf{V}_{\text {Max }}$ & $\begin{array}{c}\text { Intervalo de } \\
\text { referencia }^{*}\end{array}$ \\
\hline $\begin{array}{c}N a, g L^{-1} \\
n=6\end{array}$ & 3,16 & 0,16 & 3,01 & 3,72 & $2,75-3,54$ \\
& $3,27^{\mathrm{a}}$ & & & & \\
$\begin{array}{c}C l, g L^{-1} \\
n=8\end{array}$ & 5,18 & 0,25 & 5,02 & 5,48 & $4,25-5,45$ \\
& $5,03^{\mathrm{a}}$ & & & & \\
\hline
\end{tabular}

*Limites estabelecidos por WHO - OMS

$\mathrm{V}_{\text {Min }}$ : valor :mínimo

$\mathrm{V}_{\text {Max }}$ : valor máximo

n: numero de amostras analisadas

a : Titulometria 


\section{CAPÍTULO 8. DISCUSSÃO}

Os valores de referência obtidos para o grupo controle (Tabela 4) permitem comparar a concentração dos elementos no sangue de eqüinos em função do sexo. Essa análise indica um aumento na concentração de $\mathrm{Br}, \mathrm{Ca}, \mathrm{P}$, $\mathrm{Fe}, \mathrm{I}, \mathrm{K}, \mathrm{Mg}$ e $\mathrm{Zn}$ em fêmeas em relação aos machos enquanto que para $\mathrm{Na}, \mathrm{Cl}$ e $S$ este comportamento é invertido. Este comportamento pode estar relacionado a diferenças hormonais (período de lactação) e fisiológicas entre machos e fêmeas. Para a comparação das medidas dos gêneros (macho e fêmea) foi utilizado o Teste - $t$ (ANEXO -6). Os resultados para os elementos magnésio, ferro e potássio, com o nível de significância utilizado $(p<0,05)$ apresentam evidências suficientes para descartar a hipóteses de igualdade entre os gêneros.

Em relação ao grupo recém imunizado (Tabela 5), as concentrações obtidas para $\mathrm{Na}$ e $\mathrm{K}$ encontra-se dentro do intervalo de confiabilidade de $68 \%$ enquanto para $\mathrm{Ca}, \mathrm{Cl}, \mathrm{Fe}, \mathrm{I}, \mathrm{Mg}, \mathrm{S}$ e $\mathrm{P}$ os resultados obtidos só são compatíveis para o intervalo de confiabilidade de $95 \%$ (considerando os limites estabelecidos para grupo controle constituídos por machos). Entretanto, observa-se nos valores para Ca e I uma diminuição e as concentrações encontram-se próximas aos limites inferiores $\left(0,143-0,177 \mathrm{gL}^{-1}\right.$ para $\circ \mathrm{Ca} ; 0,0001-0,0007 \mathrm{gL}^{-1}$ para $\left.\circ \mathrm{I}\right)$ enquanto para $\circ \mathrm{Cl}$ e $\mathrm{Mg}$ os resultados encontram-se dentro dos limites superiores $\left(2,99-3,18 \mathrm{gL}^{-1}\right.$ para $\mathrm{Cl} ; 0,053-0,060 \mathrm{gL}^{-1}$ para $\left.\mathrm{Mg}\right)$. Em relação ao elemento cálcio a diminuição no seu nível sanguíneo pode estar associada a alta concentração de fósforo na ração $\left(46 \mathrm{gkg}^{-1}\right)$, que conjugado com o cálcio, tende a diminuir sua absorção [21]. Da mesma forma o decréscimo na concentração de iodo no grupo imunizado, pode ser devido a alta concentração de zinco na ração (2,3 g/kg), que ao se conjugar com o iodo pode inibir sua absorção [21]. Com relação aos cloretos sua alta concentração na dieta (incluindo ração e sal) juntamente com o magnésio podem estar contribuindo para seu aumento nos níveis sanguíneos. Também para $\mathrm{Br}$ e $\mathrm{Zn}$ os dados obtidos para Gl mostram -se em parte fora dos limites de normalidade, mesmo considerando -se um intervalo de confiabilidade de $99 \%\left([0,0001-0,0046] \mathrm{gL}^{-1}\right.$ para $\mathrm{Br}$; e $[0,288-0,708] \mathrm{gL}^{-1}$ 
para $\mathrm{Zn}$ ). A diminuição na concentração de $\mathrm{Br}$ especificamente nas amostras $1 \mathrm{e}$ 2 do Gl e o aumento na concentração de Zn nessas amostras (Figura 13), enfatizam este comportamento.

Para elucidar um pouco mais o comportamento desses elementos no sangue foi gerada a matriz de correlações do GC (Tabela 6) dos elementos investigados em sangue. As relações prioritárias neste grupo são expressas pelas relações diretas (correlações positivas) entre os elementos, tais como: $\mathrm{Br}$ e Zn $(+0,87)$, I e K $(+0,77)$ e Ca e Mg $(+0,68)$; ou seja, o aumento dos níveis de $\mathrm{Br}$, I e Ca no sangue levam ao aumento dos níveis de $\mathrm{Mg}, \mathrm{K}$ e $\mathrm{Zn}$, respectivamente e vice - versa, mas não necessariamente na mesma proporção, evidenciando uma forte dependência entre esses elementos nos sangue e, portanto, a necessidade de monitoração constante. No caso do cálcio em relação ao magnésio, esta correlação já havia sido previamente descrita na literatura [21]. Com menor intensidade as correlações entre $\mathrm{Ca}$ e $\mathrm{Cl}(-0,53), \mathrm{Br}$ e S $(-0,51)$ e $\mathrm{Na}$ e Fe $(-0,46)$ sugerem uma dependência indireta (correlação inversa) entre esses eletrólitos, ou seja, quando uma aumenta a outra diminui, mas não necessariamente na mesma proporção.

Para uma avaliação do comportamento das correlações no sangue do GI foram geradas as matrizes de correlação tanto para grupo controle constituído só por machos (Tabela 10) quanto para o grupo imunizado (Tabela 11). 
Tabela 10: Matriz de correlação em sangue total para os elementos determinados em sangue total no grupo controle (machos); as relações prioritárias encontramse em destaque.

\begin{tabular}{|c|c|c|c|c|c|c|c|c|c|c|c|}
\hline & $\mathrm{Br}$ & $\mathrm{Ca}$ & Cl & I & K & $\mathrm{Mg}$ & $\mathrm{Na}$ & $\mathbf{S}$ & $\mathrm{Fe}$ & $\mathrm{Zn}$ & $\mathbf{P}$ \\
\hline $\mathrm{Br}$ & 1 & 0,16 & - 0,72 & 0,03 & 0,11 & 0,32 & $-0,24$ & 0,07 & 0,50 & 0,92 & 0,34 \\
\hline $\mathrm{Ca}$ & & 1 & $-0,39$ & 0,22 & 0,33 & 0,67 & 0,02 & 0,11 & $-0,26$ & 0,19 & 0,38 \\
\hline Cl & & & 1 & 0,20 & 0,23 & $-0,61$ & 0,63 & 0,14 & $-0,54$ & $-0,60$ & $-0,40$ \\
\hline I & & & & 1 & 0,86 & 0,41 & 0,82 & 0,04 & $-0,17$ & $-0,12$ & 0,41 \\
\hline K & & & & & 1 & 0,47 & 0,88 & 0,08 & $-0,33$ & 0,03 & 0,20 \\
\hline Mg & & & & & & 1 & 0,08 & $-0,29$ & 0,17 & 0,15 & 0,53 \\
\hline $\mathrm{Na}$ & & & & & & & 1 & 0,15 & $-0,47$ & $-0,30$ & 0,01 \\
\hline $\mathbf{S}$ & & & & & & & & 1 & $-0,70$ & 0,00 & $-0,59$ \\
\hline $\mathrm{Fe}$ & & & & & & & & & 1 & 0,45 & 0,63 \\
\hline $\mathrm{Zn}$ & & & & & & & & & & 1 & 0,30 \\
\hline P & & & & & & & & & & & \\
\hline
\end{tabular}


Tabela 11: Matriz de correlação em sangue total para os elementos determinados em sangue total no grupo imunizado (Gl); as relações prioritárias encontram-se em destaque.

\begin{tabular}{|c|c|c|c|c|c|c|c|c|c|c|c|}
\hline & $\mathrm{Br}$ & $\mathrm{Ca}$ & $\mathrm{Cl}$ & I & $\mathrm{K}$ & $\mathbf{M g}$ & $\mathrm{Na}$ & $\mathbf{S}$ & $\mathrm{Fe}$ & $\mathrm{Zn}$ & $\mathbf{P}$ \\
\hline $\mathrm{Br}$ & 1 & 0,64 & $-0,78$ & 0,04 & $-0,41$ & $-0,48$ & $-0,97$ & 0,29 & 0,51 & $-0,51$ & 0,68 \\
\hline $\mathrm{Ca}$ & & 1 & $-0,07$ & $-0,32$ & $-0,15$ & $-0,53$ & $-0,66$ & 0,37 & $-0,07$ & $-0,18$ & 0,69 \\
\hline $\mathrm{Cl}$ & & & 1 & $-0,28$ & 0,59 & 0,24 & 0,68 & $-0,17$ & $-0,77$ & 0,28 & $-0,32$ \\
\hline I & & & & 1 & $-0,60$ & $-0,42$ & 0,09 & $-0,29$ & 0,31 & $-0,09$ & $-0,48$ \\
\hline K & & & & & 1 & 0,55 & 0,18 & 0,11 & $-0,54$ & $-0,34$ & 0,04 \\
\hline Mg & & & & & & 1 & 0,33 & 0,50 & $-0,52$ & 0,04 & 0,11 \\
\hline $\mathrm{Na}$ & & & & & & & 1 & $-0,38$ & $-0,33$ & 0,66 & $-0,79$ \\
\hline$S$ & & & & & & & & 1 & $-0,29$ & $-0,41$ & 0,82 \\
\hline $\mathrm{Fe}$ & & & & & & & & & 1 & 0,00 & $-0,20$ \\
\hline Zn & & & & & & & & & & 1 & 0,03 \\
\hline $\mathbf{P}$ & & & & & & & & & & & 1 \\
\hline
\end{tabular}


De acordo com a Tabela 10 as relações prioritárias identificadas no GC são dadas pelas correlações diretas entre: bromo e zinco $(0,92)$, iodo e potássio $(0,86)$, sódio com iodo $(0,82)$ e sódio com potássio $(0,88)$, além de correlações indiretas entre o ferro e enxofre $(-0,70)$ e entre bromo e cloro $(-0,72)$. Em relação ao Gl (Tabela 11) somente a correlação indireta entre bromo e cloro se manteve (-0,72 CG e -0,78 Gl). O iodo e o potássio (+0,86 GC e -0,60 Gl); cálcio e o magnésio (+0,67 GC e -0,53 Gl) e também o zinco e bromo (+0,92 GC e -0,51 Gl) tiveram correlações invertidas. Outros elementos como bromo, sódio e fósforo acentuaram suas correlações: $\mathrm{Na}$ e $\mathrm{Br}(-0,24 \mathrm{GC}$ e -0,97 Gl), $\mathrm{P}$ e $\mathrm{Br}(+0,34 \mathrm{GC}$ e $+0,68 \mathrm{Gl}), \mathrm{P}$ e Ca $(+0,38 \mathrm{GC}$ e +0,69 Gl). Uma correlação foi invertida entre $\mathrm{P}$ e $\mathrm{S}$ (-0,59 GC e +0,82 Gl) e também uma forte correlação entre $P$ e Na (-0,79 Gl) foi evidenciada sem nenhum indício de correlação no grupo controle. Considerando que essas análises foram realizadas em amostras de sangue coletadas imediatamente após o processo de imunização, para uma avaliação mais realista, faz-se necessário o estudo do comportamento desses elementos no sangue imunizado em função do tempo (durante vários ciclos de imunização), gerando dados que possam esclarecer com que intensidade a imunização interfere no organismo, isto é, se essas correlações são momentâneas, mantidas, intensificadas ou revertidas.

Com relação à análise realizada na ração, além dos elementos especificados, tem-se a presença de potássio em significativa concentração $\left(14 \mathrm{gkg}^{-1}\right)$ além de bromo e vanádio. $O$ fabricante não menciona a presença desses minerais na composição da ração e também não fornece a concentração de cloretos. Além disso, uma comparação em termos de valor absoluto não é possível, pois a especificação dos elementos na ração é fornecida pela concentração mínima esperada.

Com relação às análises feitas com o sal consumido pelos animais, identificou-se em sua composição a presença de $\mathrm{Ca}, \mathrm{Cl}, \mathrm{I}, \mathrm{Mg}, \mathrm{Na}, \mathrm{P}$ e V. No caso do fósforo, o fabricante especifica que a concentração mínima é de $80 \mathrm{~g} / \mathrm{kg}^{-1}$, entretanto as análises por AAN mostram um dado significativa menor (12,0 $\left.\mathrm{g} \mathrm{kg}^{-1}\right)$. Os cloretos $\left(\sim 130 \mathrm{gkg}^{-1}\right)$ bem como o vanádio $\left(\sim 0,7 \mathrm{mgkg}^{-1}\right)$ não são 
especificados pelo fabricante. Os elementos cálcio, iodo, magnésio e sódio encontram-se em acordo com a especificação do fabricante.

Embora os animais não apresentem desnutrição ou disfunção vinculada a intoxição dietética, as análises realizadas sugerem a necessidade de uma avaliação mais precisa da oferta de alimento deve ser realizada, possibilitando uma alimentação equilibrada e devidamente balanceada em nutrientes essências. Além disso, considerando que esses animais, tanto CG com Gl, irão ou estão iniciando suas atividades como doadores de plasma, esta avaliação poderá ser útil também para o monitoramento do status clinico destes animais durante os vários ciclos de imunização.

Com relação à análise feita no soro antibotrópico (antiveneno) verificouse que os valores obtidos pela técnica de Titulometria para $\mathrm{Na}$ e $\mathrm{Cl}$ foram compatíveis com os valores obtidos pela técnica de Análise por Ativação com Nêutrons. 


\section{CAPÍTULO 9. CONCLUSÃO}

O procedimento de análise por ativação com nêutrons (AAN) foi utilizado como alternativa para obtenção de valores de referência de eletrólitos em sangue total de cavalos da raça Crioula, utilizados na produção de soros hiperimunes do Instituto Butantan, sendo esses os primeiros índices estabelecidos para esta raça.

Com relação ao acompanhamento clinico, via AAN, do grupo recém imunizado (Gl) tem se que a maioria dos elementos investigados em sangue ( $\mathrm{Ca}$, $\mathrm{Cl}, \mathrm{Fe}, \mathrm{I}, \mathrm{K}, \mathrm{Na}, \mathrm{S}$ e P) encontram-se dentro de limite de normalidade estabelecido pelo presente estudo (para o intervalo de confiabilidade de $95 \%$ usualmente adotado na pratica clinica), entretanto alterações significativas nos níveis de $\mathrm{Zn}$, $\mathrm{Mg}$ e $\mathrm{Br}$ sugerem que esses elementos poderiam ser avaliados durante os consecutivos ciclos de imunização. Outras evidências foram constadas através da comparação entre os coeficientes de correlação do GC (machos) com o Gl, que além de enfatizar a necessidade de monitoração de $\mathrm{Br}$, e $\mathrm{Zn}$ sugere também que a análise de $\mathrm{P}$, dada as fortes correlações (diretas ou indiretas) com vários elementos ( $\mathrm{Br}, \mathrm{Ca}, \mathrm{Na}$ e S).

A análise na dieta desses animais (ração e sal) via AAN, evidenciou algumas discrepâncias enfatizando a necessidade do acompanhamento nutricional desses animais.

Os resultados obtidos na análise do soro antibotrópico (teste físico químicos) via AAN, encontram-se de acordo com as especificações da ANVISA assegurando a qualidade deste imunobiológico. 


\section{PERSPECTIVAS}

Em função das mudanças significativas nas correlações entre GC (machos) e Gl fica evidente a necessidade de se investigar o comportamento sanguíneo de um determinado grupo de cavalos em função do tempo (durante os ciclos de imunização). Desta forma, durante o período de maio a dezembro de 2009, que compõe 4 ciclos de imunização, foram realizadas coletas de sangue em 20 cavalos (machos) da raça Crioula no Instituto Butantan, antes da primeira imunização (para controle) e durante todas as etapas que compõem um ciclo de imunização (após 10 dias da primeira dose (emulsão múltipla completa-EMC); após 7 dias da segunda dose (emulsão múltipla incompleta-EMI); após 10 dias da terceira dose PBS; após 30 dias de descanso no animal até o começo do segundo ciclo de imunização - total de quatro coletas nos respectivos 20 animais / ciclo de imunização), seguindo os procedimento estabelecido em na seção 6.2 . Desta forma, o procedimento de AAN poderá ser empregado para o acompanhamento clínico desses animais durante os ciclos de imunização, gerando dados que possam otimizar e/ou redimensionar estes ciclos, e também contribuindo para o bem estar animal. 


\section{Anexo 1 : Cálculo das áreas dos fotopicos}

Para esta tarefa foi utilizado o programa IDEFIX [32], que permite ajuste de um fotopico utilizando uma função gaussiana.

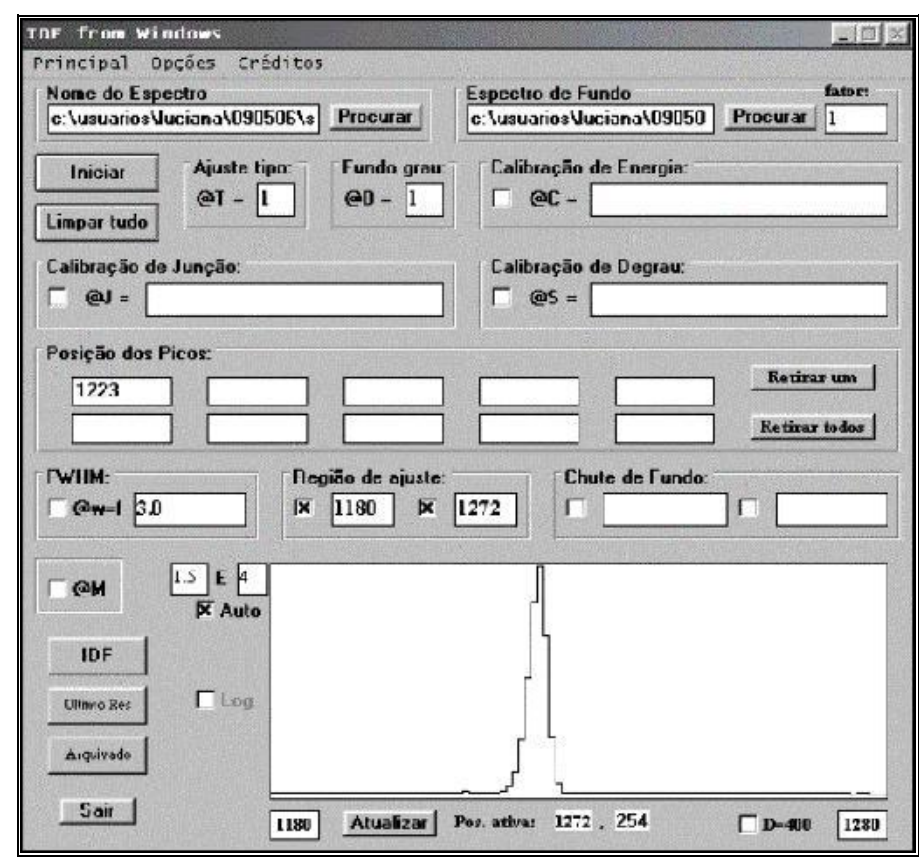

Seleção do pico para se calcular sua área.

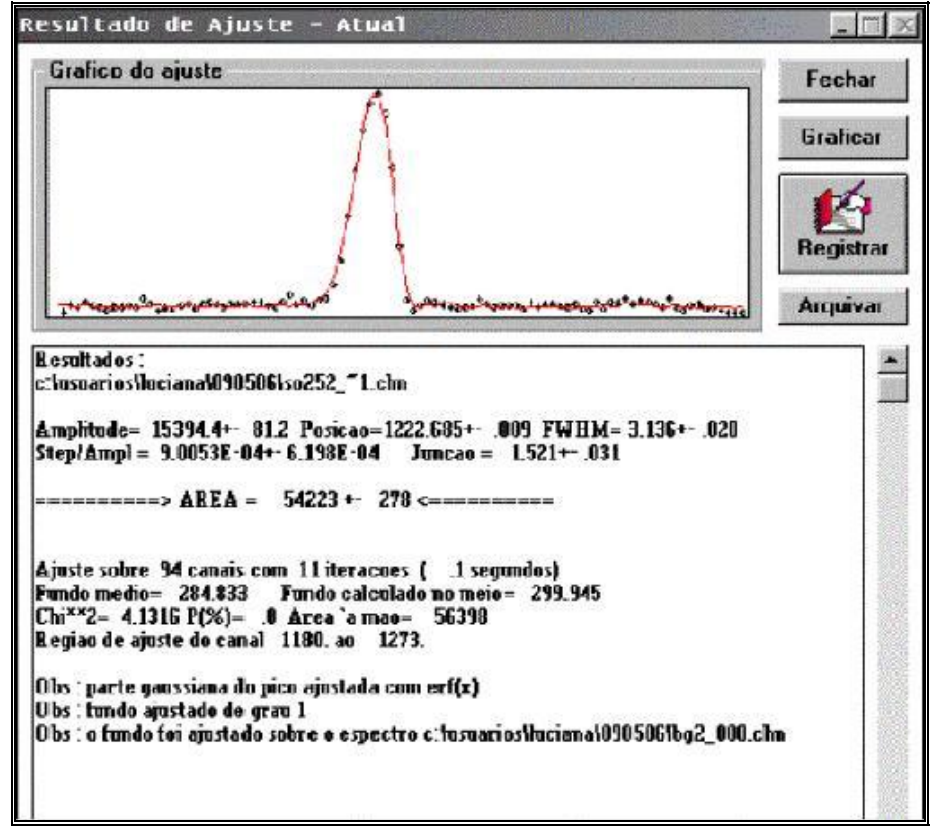




\section{Anexo 2 : Cálculo da concentração dos elementos e do fluxo}

Para esta tarefa foi utilizado o programa Ativação [33], que calcula a concentração do elemento desejado e o fluxo de nêutrons do reator IEA - R1.

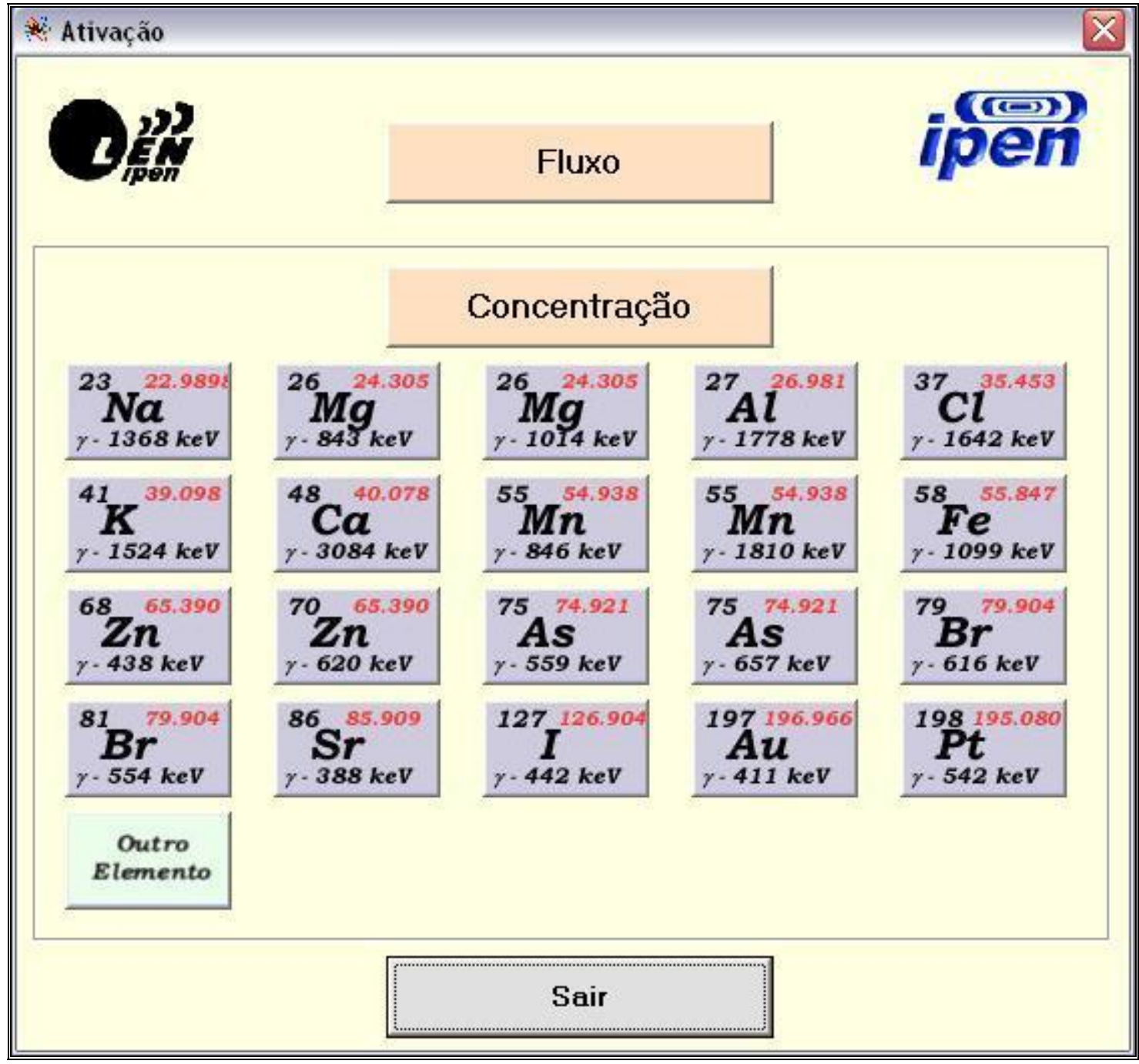

Tela principal onde se escolhe o elemento para calcular a concentração desejada. 


\section{Anexo 3 : Tela do software para cálculo da concentração}

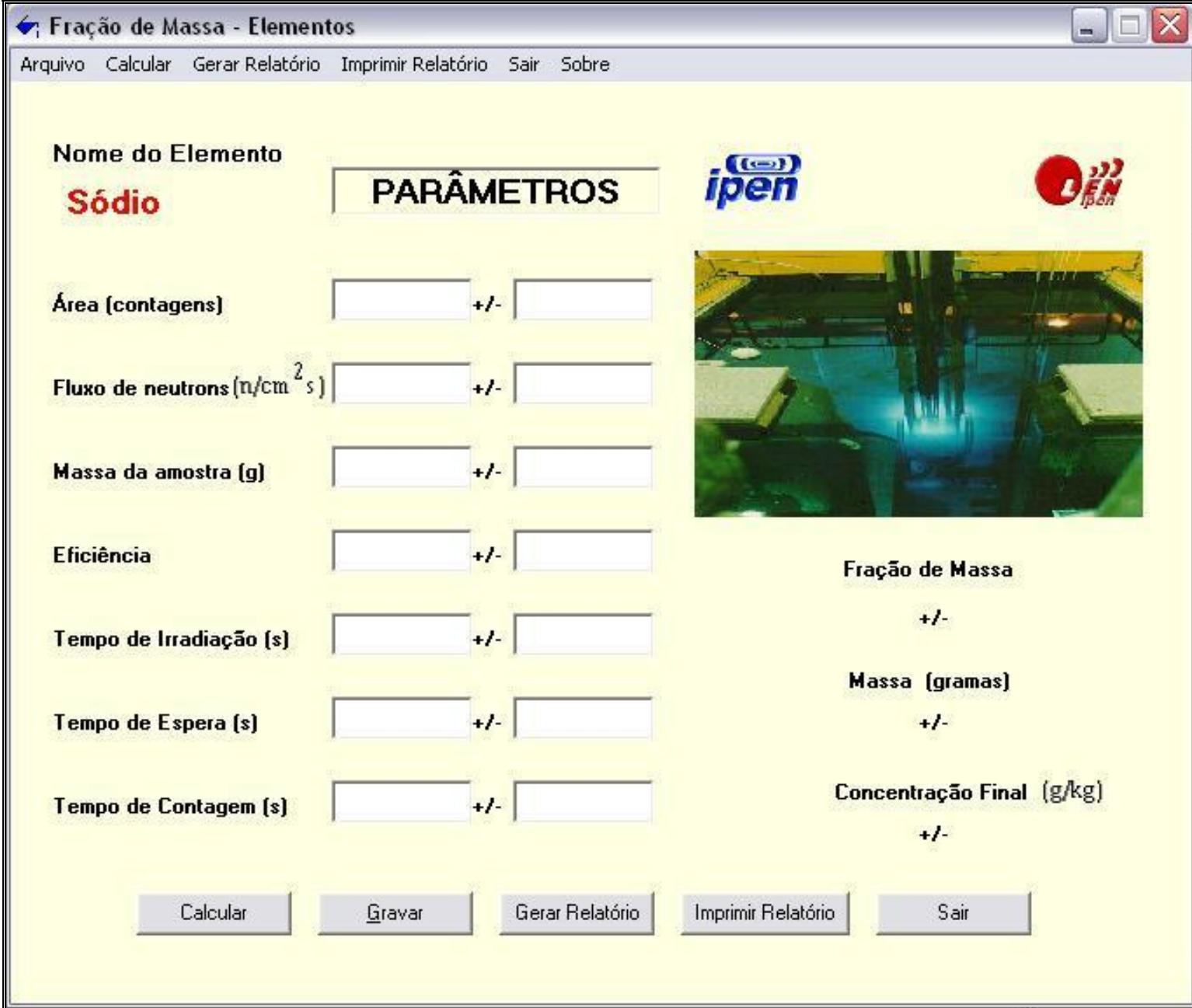




\section{Anexo 4 : Tela do software para cálculo do fluxo de nêutrons}

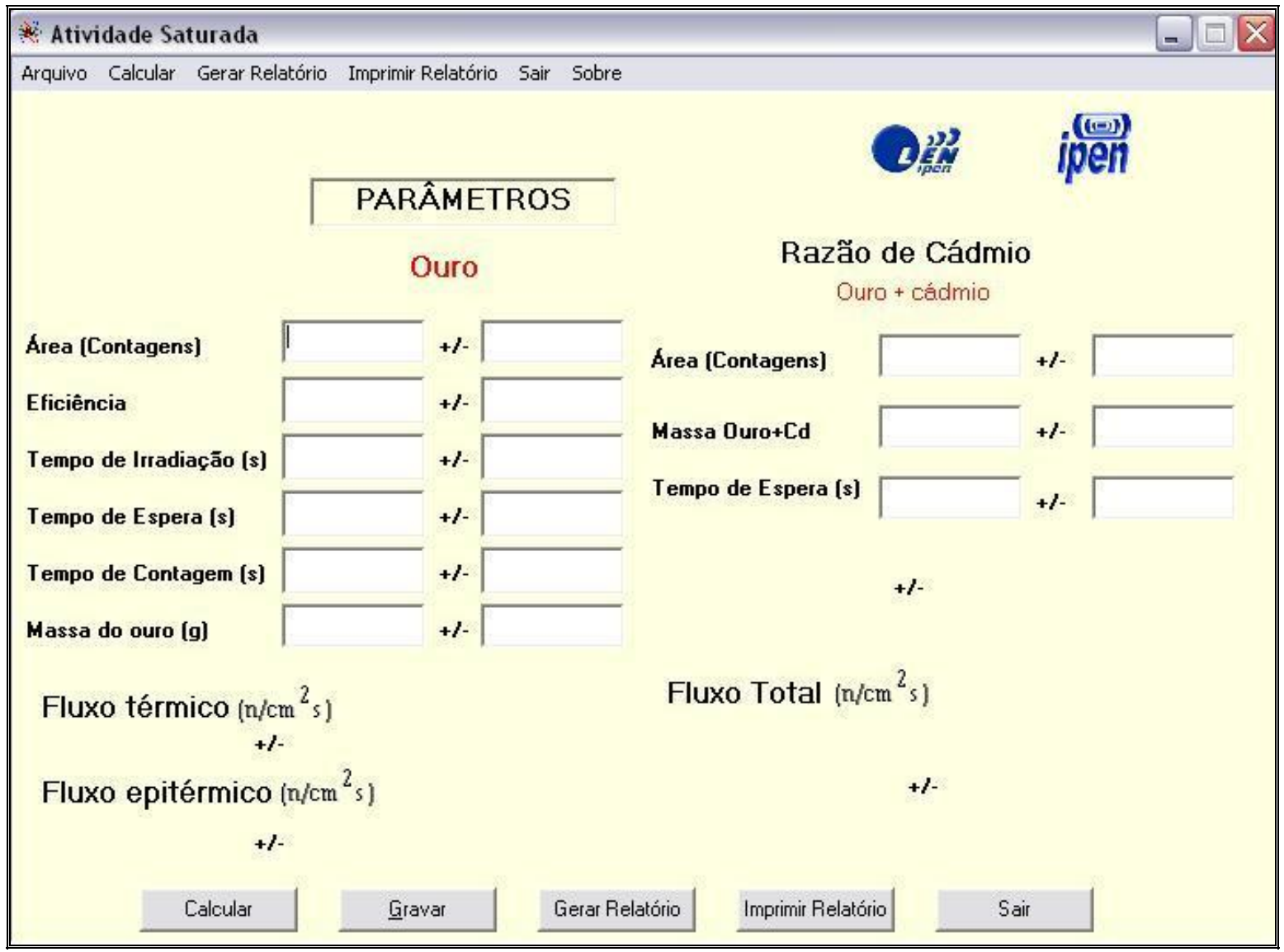




\section{ANEXO 5: Análise das correlações de Pearson}

Em estatística, correlação de Pearson mede a relação linear entre duas variáveis quantitativas aleatórias.

O coeficiente de correlação entre duas variáveis aleatórias $X$ e $Y$ é expresso pela relação:

$r=\frac{\sigma_{X Y}}{\sigma_{X} \cdot \sigma_{Y}}$

onde

$\sigma_{X Y}$ covariância de $(X, Y)$

$\sigma_{Y} \sigma_{X}$ e desvios padrão das variáveis $X$ e $Y$

Para esta análise considera-se o valor de cada variável $X_{\mathrm{ii}}(\mathrm{j}=1, \ldots, \mathrm{m}$ elementos $)$ em cada amostra analisada ( $i=1, \ldots ., N$ amostras), sendo a correlação entre os elementos medidos, por exemplo $\mathrm{X}_{1}$ e $\mathrm{X}_{2}$, expressa por:

$$
\rho_{12}=\operatorname{cov}\left(\mathrm{X}_{1} \mathrm{X}_{2}\right) / \sigma_{\mathrm{x} 1} \cdot \sigma_{\mathrm{x} 2}
$$

onde

$$
\operatorname{cov}\left(\mathrm{X}_{1} \mathrm{X}_{2}\right)=\Sigma\left(\mathrm{X}_{11}-\mathrm{X}_{1}{ }^{\mathrm{m}}\right)\left(\mathrm{X}_{21}-\mathrm{X}_{2}{ }^{\mathrm{m}}\right) / \mathrm{N}-1
$$

para

$\mathbf{X}_{\mathbf{j}}^{\mathrm{m}} \quad$ valor médio da variável $\mathrm{j}$ nas $\mathrm{N}$ amostras medidas

$\sigma_{\mathbf{x j}}$ desvio padrão da variável $\mathbf{X}_{\mathbf{j}}$

O valor do índice de correlação varia no intervalo $[-1,+1]$, de modo que:

Se $r=1$ existe uma correlação positiva perfeita. $O$ índice +1 indica uma dependência total entre as duas variáveis (relação direta), isto é, quando um aumenta, o mesmo acontece com a outra na mesma proporção.

Se $0<r<1$ há uma correlação positiva: quando um aumenta, o mesmo acontece com a outra, não necessariamente na mesma proporção. 
Se $r=0$, não existe uma relação linear, mas isso não implica necessariamente que as variáveis são independentes.

Se $r=-1$, a correlação perfeita negativa. $O$ índice -1 indica uma dependência total entre as duas variáveis (relação inversa): quando uma aumenta a outra diminui na mesma proporção.

Se $-1<r<0$, há uma correlação negativa; quando uma aumenta a outra diminui, não necessariamente na mesma proporção. 


\section{ANEXO 6: TEST - $t$}

O teste - $t$ é empregado para se verificar se duas médias (entre amostras independentes) são iguais. Considerando -se o nível de significância de 0,05 para a hipótese de igualdade (hipótese H0), tem - se que:

Se $p<0,05$ rejeita-se $\mathrm{H} 0$.

Se $\mathrm{P}>0,05$ não podemos rejeitar H0.

Para isto calcula - se a estatística $t$ que é dada pela seguinte equação:

$$
t=\frac{\bar{x}_{1}-\bar{x}_{2}}{\mathrm{SE}_{12}}
$$

O denominador é calculado com:

$$
\mathrm{SE}_{12}=\mathrm{S} \sqrt{\frac{1}{n_{1}}+\frac{1}{n_{2}}}
$$

para

$$
\mathrm{S}^{2}=\frac{\left(n_{1}-1\right) s_{1}^{2}+\left(n_{2}-1\right) s_{2}^{2}}{n_{1}+n_{2}-2}
$$

onde:

$\bar{x}_{1}$ e $\bar{x}_{2}$ são as médias aritméticas dos dois conjuntos de números

$s_{1}$ e $s_{2}$ são as raízes quadradas das variâncias dos dois conjuntos

$n_{1}$ e $n_{2}$ são os números de pontos em cada conjunto. 


\section{REFERÊNCIAS BIBLIOGRÁFICAS}

[1] AFFONSO, A.; CORREA, S. Cavalo crioulo: uma história de raça. Porto Alegre: Sagra, p. 210, 1992.

[2] ALMEIDA, M.A.Z.; SILVA, N.M. Determinação dos valores hematológicos normais do cavalo (Equus caballus, Linnaeus) da raça Crioula. A hora veterinária, v.15, n. 87, p.48-50, 1995.

[3] NAVIAUX, J.L. Cavalos na saúde e na doença, 2 ed, São Paulo, p.103-104, 1988.

[4] MANUAL MERCK DE VETERINÁRIA, 8 ed, São Paulo, 2001.

[5] ZAMBONI, C. B; MEDEIROS, I. M. A; GENEZINI, F. A. Nuclear methodology to study kidney anomalies. V National Meeting on Nuclear Applications, Brasil, 2000.

[6] OLIVEIRA, L. C.; ZAMBONI, C. B. ; CESTARI, A. C. ; DALAQUA JR, L ; GUEVARA, M. V. MANSO ; FIGUEIREDO, A. M. G. ; ARRUDA-NETO, J. T. . Nuclear methodology for studying biological functions of mammalians submitted to uranium ingestion. Revista Brasileira de Pesquisa e Desenvolvimento, Brasil, v. 4, n. 3, p. 1035-1039, 2002.

[7] FIGUEIREDO, A. M. G; SAIKI, M; ZAMBONI, C. B; OLIVEIRA, L. C; MEDEIROS, J. A. G. Comparasion of absolute NAA by using cadmium ration technique with comparative NAA to determine trace elements in fisiological samples aiming clinical analysis. V Latinamerican Symposium Nuclear Physics, Santos, 2003.

[8] CESTARI, A. C.; ARRUDA-NETO, J. T.; ZAMBONI, C. B. ; OlIVRIA, L. C. ; PEREZ, A C ; GONÇALVES, O. D. ; MAGALHÃES, S. D. XRF and NAA of trace elements in poutry bone. In: V Latinamerican Symposium on Nuclear Physics, Santos. Program and Abstracts. v.1, p. 31, 2003.

[9] ZAMBONI, C. B.; FIGUEIREDO, A. M. G.; SAIKI, M.; CESTARI, A. C.; ARRUDA-NETO, J. $T$. Uranium incorporation investigation in wister rats bone. In: $\mathbf{V}$ encontro Nacional de Aplicações Nucleares, 2000, Rio de Janeiro. Proceedings V ENAN, 2000.

[10] OLIVEIRA, L. C; ZAMBONI, C. B; FIGUEIREDO, A. M. G; CESTARI, A. C; ARRUDANETO, J. T. Nuclear methodology to perform clinical examination of urine. III Encontro Nacional de Biociências Nucleares, Brasil, 2001.

[11] OLIVEIRA, L. C; ZAMBONI, C. B; ZAHN, G. S; RAELE, M. P; MASCHIO, M. Use of thermal neutrons to perform analyses in body organs of small sized animals. Brazilian Journal of Physics, v. 34, p. 811, 2004.

[12] OLIVRIA, L. C. ; ZAMBONI, C. B. ; GENEZINI, F. A ; FIGUEIREDO, A. M. G; ZAHN, G.S. Use of thermal neutrons to perform clinical analyses in blood and urine samples. Journal of Radioanalytical and Nuclear Chemistry, v. 263, n. 3, p. 783-786, 2005.

[13] ZAMBONI, C. B. ; ZAHN, G Z ; SANT'ANNA, O. A. Trace elements at whole blood of distinct mouse lines by using NAA. AIP Conference Proceedings, v. 884. p. 507-509, 2007.

[14] ZAMBONI, C. B.; SUZUKI, M.F.; METAIRON, S. ; CARVALHO, M. F. D. ; SANT'ANNA, O. $A$. Investigation of whole blood of SJL/J mice using neutron activation analysis. Journal of Radioanalytical and Nuclear Chemistry, v. 281, p. 97-99, 2009.

[15] OLIVEIRA L. C, ZAMBONI C. B, LINS P. S, AZEVEDO M. R. The chlorine reference value in whole blood using ANAA. Brazilian Journal of Physics, v.35, n. 3b, p. 793-796, 2005. 
[16] ZAMBONI, C. B; OLIVEIRA, L. C; DALAQUA JR., L. Diagnostic application of absolute neutron activation analysis in hematology. America Nuclear Energy Symposium ANES, Florida, 2004.

[17] OLIVEIRA L. C,. ZAMBONI C. B. Realização de análises clínicas utilizando processo radioanalítico. $39^{\circ}$ Congresso Brasileiro de Patologia Clínica/Medicina Laboratorial, São Paulo, 2005.

[18] KOVACS, L ; ZAMBONI, C. B. ; OLIVRIA, L. C.; SALVADOR, V.L.R. ; SATO, I, M. ; AZEVEDO, M. R. Analysis of serum and whole blood using NAA for clinical investigation. Journal of Radioanalytical and Nuclear Chemistry, v. 278, p. 543-545, 2008.

[19] FRÉJAVILLE, J.P.; KAMOUN, P. (eds) Guide des exames de laboratoire. Paris. Flammarion, 1981.

[20] Doença genética pode estar relacionada à deficiência de minerais. Revista Espaço Aberto, edição 94, agosto 2008. Universidade de São Paulo. Disponível em http://www.usp.br/espaçoaberto/Onotasa.htm. Acessado em 29 out. 2009.

[21] LEWIS, L.D. Nutrição Equina: Alimentação e cuidados. São Paulo. Ed Roca, p. 29-73, 2000.

[22] BACILA, M. Bioquímica veterinária. São Paulo. Ed. Robe Editorial, p. 365, 2003.

[23] SILVA M.A.M.L; FILHO R.M.P; et al. Determinação das concentrações de cobre e zinco séricos de eqüinos da região de Espírito Santo do Pinhal. Boletim Medicina Veterinária, Espírito Santo do Pinhal v.3, n.3, p. 24-34, jan/dez 2007.

[24] Associação Brasileira dos Criadores de Cavalos Crioulos. ABCCC. Disponível em <http//: www.abccc.com.br>. Acesso em: 24 set. 2008.

[25] BECK, S.L. Eqüinos: raças, manejo, equitação. 2 ed. São Paulo: Editora dos Criadores, p 703, 1989.

[26] TORRES, A DI PARAVICINI; WALTER R. Criação de cavalos e outros eqüinos. Editora Nobel, 1987.

[27] VITAL BRAZIL, O. History of the primordia of snake-bite accident serotherapy. Memórias do Instituto Butantan, v.49, n.1, p.7-20, 1987.

[28] ANTHONY T.TU. Handbook of natural toxins - Reptile venoms and toxins, v.5, Ed Marcel Dekker, New York, p.529-552, 1992.

[29] FURTADO, M. F. D.; COLLETO, G.M.D.D.; DIAS DA SILVA. Controle de qualidade dos venenos animais e dos correspondentes antivenenos. Memórias do Instituto Butantan, v.53, n.2, p.149-159, 1991.

[30] ZAMBONI, C. B.. Fundamentos da Física de Nêutrons. 1ed Livraria da Física, São Paulo, 2007.

[31] INTERNATIONNAL ATOMIC ENERGY AGENCY. X-Ray and Gamma-Ray Standards for detector calibration. (IAEA - TECDOC - 619), Viena, 1991.

[32] GOFFON, P. Manual do programa IDF. São Paulo: Universidade de São Paulo, IFUSP, 1987.

[33] MEDEIROS, J.A.G. , ZAMBONI, C. B., ZAHN, G. S. , OLIVEIRA, L. C., DALAQUA, L. Jr. Software para realização de análises hematológicas utilizando processo radioanalítico. $39^{\circ}$ Congresso Brasileiro de Patologia Clinica / Medicina Laboratorial, de 19 a 22 de outubro, São Paulo - SP, Brasil, 2005. 
[34] VERSIECK, J.; VANBALLENBERGHE, L.; DE KESEL, A.; HOSTE, J.; WALLAEYS, B.; VANDENHAUTE, J.; BAECK, N.; STEYAERT, H.; BYRNE, A. R.; SUNDERMAN, F. W. JR. The second- generation Biological reference material Freeze - Dried Human Serum Anal. Chim. Acta, v. 204, p. 63, 1988.

[35] JOHNSON, R.A.; WICHERN, D.W. Applied Multivariate Statistical Analysis. Fifth Edition, Prentice Hall, 2001. 